\title{
Late Quaternary speleogenesis and landscape evolution in a tropical carbonate island: Pango la Kuumbi (Kuumbi Cave), Zanzibar
}

\author{
Nikos Kourampas ${ }^{1^{*}}$, Ceri Shipton ${ }^{2}$, William Mills ${ }^{3}$, Ruth Tibesasa ${ }^{4}$, Henrietta Horton $^{5}$, \\ Mark Horton ${ }^{6}$, Mary Prendergast ${ }^{7}$, Alison Crowther ${ }^{8}$, Katerina Douka ${ }^{3}$, Patrick Faulkner ${ }^{9}$, \\ Llorenç Picornell ${ }^{10}$, and Nicole Boivin ${ }^{3}$ \\ ${ }^{1}$ Biological and Environmental Sciences, University of Stirling, \& Office of Lifelong Learning, University of Edinburgh, Scotland, UK \\ ${ }^{2}$ British Institute in Eastern Africa, Nairobi, \& McDonald Institute for Archaeological Research, University of Cambridge, UK \\ ${ }^{3}$ School of Archaeology, University of Oxford, UK \\ ${ }^{4}$ History Department, Kyambogo University, Uganda \\ ${ }^{5}$ The MENTOR Initiative, Monrovia, Liberia \\ ${ }^{6}$ School of Archaeology, University of Bristol, UK \\ ${ }^{7}$ Department of Sociology and Anthropology, St. Louis University in Madrid, Spain \\ ${ }^{8}$ School of Social Science, The University of Queensland, Australia \\ ${ }^{9}$ Department of Archaeology, School of Philosophical and Historical Inquiry, The University of Sydney, Australia \\ ${ }^{10}$ Department of Historical Sciences and Theory of Art, University of the Balearic Islands, Spain
}

\begin{abstract}
Kuumbi Cave is one of a group of caves that underlie a flight of marine terraces in Pleistocene limestone in eastern Zanzibar (Indian Ocean). Drawing on the findings of geoarchaeological field survey and archaeological excavation, we discuss the formation and evolution of Kuumbi Cave and its wider littoral landscape. In the later part of the Quaternary (last ca. 250,000 years?), speleogenesis and terrace formation were driven by the interplay between glacioeustatic sea level change and crustal uplift at rates of ca. $0.10-0.20 \mathrm{~mm} / \mathrm{yr}$. Two units of backreef/reef limestone were deposited during 'optimal' (highest) highstands, tentatively correlated with MIS 7 and 5; (mainly) erosive marine terraces formed in these limestones in 'suboptimal' highstands. Kuumbi and other sub-terrace caves developed as flank margin caves, in the seaward portion of freshwater lenses during such 'suboptimal' highstands. Glacioeustacy-induced fluctuations of the groundwater table may have resulted in shifts from vadose (with deposition of well-developed speleothems) to phreatic/epiphreatic conditions in these caves. At Kuumbi, Late Pleistocene (pre-20,000 cal. BP) ceiling collapse initiated colluvial deposition near-entrance and opened the cave to large plants and animals, including humans. A phase of terminal Pleistocene human occupation ca. 18,500-17,000 cal. BP resulted in the deposition of a dense assemblage of Achatina spp. landsnails, alongside marine molluscs and mammal remains (including zebra, buffalo and other taxa now extinct on Zanzibar). The Holocene part of the cave stratigraphy near-entrance records phases of abandonment and intensified late Holocene human use.
\end{abstract}

Keywords: Carbonate Island Karst; cave deposits; archaeology; Zanzibar; East Africa

Received 15 April 2015; Revised 22 August 2015; Accepted 23 August 2015

Citation: Kourampas N., Shipton C., Mills W., Tibesasa R., Horton H., Horton M., Prendergast M., Crowther A., Douka K., Faulkner P., Picornell L. and Boivin N., 2015. Late Quaternary speleogenesis and landscape evolution in a tropical carbonate island: Pango la Kuumbi (Kuumbi Cave), Zanzibar. International Journal of Speleology, 44 (3), 293-314. Tampa, FL (USA) ISSN 0392-6672 http://dx.doi.org/10.5038/1827-806X.44.3.7

\section{INTRODUCTION}

Many islands contain extensive swathes of geologically young, eogenetic limestones that have not undergone burial diagenesis. Karst in such limestones often differs in many aspects from that in older, telogenetic limestones (e.g. Vacher \& Mylroie, 2002; Ginés \& Ginés, 2007; Mylroie, 2013). The proliferation of island cave studies in recent years reflects a recognition of the genetic distinctiveness and wider scientific significance of these landforms. The concept of flank margin speleogenesis and its more comprehensive derivative, the Carbonate Island Karst Model (Mylroie \& Carew, 1990; Mylroie et al., 1995; 2008; Mylroie \& Vacher, 1999; Mylroie \& Mylroie, 2007; Mylroie, 2013), have further highlighted this 
distinctiveness by emphasising the crucial role of carbonate dissolution in the distal, seaward part of the freshwater lens underneath carbonate islands (and, also, continental littorals). In this speleogenetic realm, discrete from those of epigenic and hypogenic speleogenesis, critical domains of carbonate dissolution (groundwater table; fresh/saltwater mixing zone) are highly responsive to relative sea level change, in turn driven by eustatic sea level change (at several timescales), and isostatic or tectonic crustal uplift or subsidence (Ginés \& Ginés, 2007; Mylroie \& Mylroie 2007; Fratesi, 2013; Ginés et al., 2014). Carbonate island caves could thus be regarded as nodes where several lines of enquiry on the workings of the earth system come together.

Related to the fundamental question of carbonate island speleogenesis is the research theme of island cave deposits: speleothems and, increasingly, detrital sediments (Sasowsky \& Mylroie, 2004; Fornós et al., 2014). As potential links between offshore and continental records, island cave deposits may be of critical import for regional and global stratigraphic
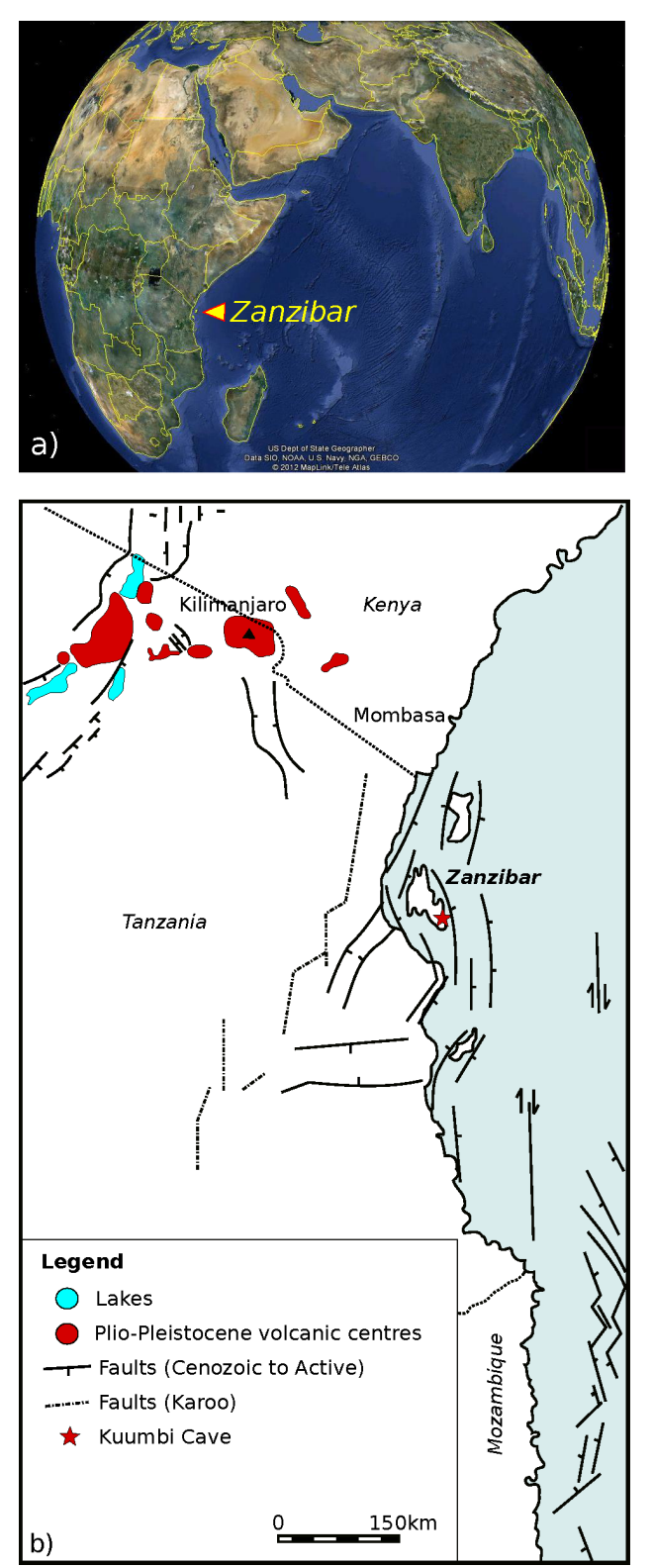

c)

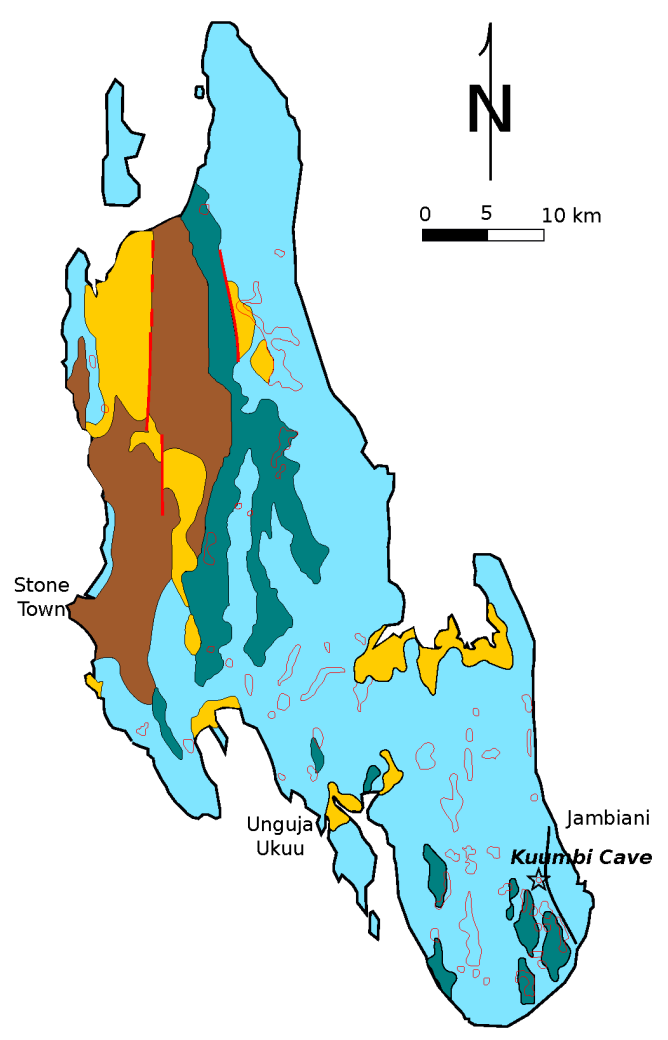

Legend
$\left.\begin{array}{|l}\hline \quad \text { Alluvia, aeolinates, latosols Late Pleistocene-Holocene } \\ \text { Azania Limestone (Mid-Late Pleistcene ?) } \\ \text { Limestone (Miocene) } \\ \text { Sandy clay, clayey sand, marl (Miocene) } \\ \text { Sand, sandstone (Miocene) }\end{array}\right]$ Tertiary
$\square \quad$ Fault
'Sinkholes' and other closed depressions
$25 \mathrm{~m}$ terrace cliff correlations of the Quaternary System. Island cave deposits contain proxies for the long-term history of large-scale, ocean basin-wide or global climatic systems (e.g. Asian Monsoon, El Niño/La Niña), sea level change, surface denudation, etc., and, also, the ecological (including human-ecological) histories of island landscapes (c.f. De Waele, 2009; Lace \& Mylroie, 2013). Such records may be crucial for understanding and modelling feedbacks between the atmosphere, the global ocean, earth surface processes, island biomes and human societies at timescales of $<10^{2}$ to $10^{6}$ years. Interpretation of island cave sediment proxies is underpinned by an understanding of how the caves that contain them, and the island landscapes of which caves are a part, form and evolve (De Waele, 2009; Bover et al., 2014; Fornós et al., 2014).

Here we attempt to reconstruct the formation and evolution of Kuumbi Cave (Pango la Kuumbi in Zanzibar's Kiswahili language), and its surrounding littoral landscape in the island of Zanzibar, equatorial Indian Ocean (Fig. 1). We do this by drawing on geological, geomorphological, stratigraphic and

Fig. 1. Zanzibar, and places mentioned in the text. a) Location; b) regional tectonic setting, with dominant directions of plate motion (thick arrows) and clockwise rotation of the Rowuma Plate (from Nicholas et al., 2007, simplified); c) geology (from United Nations, 1987 and Bron Sikat, 2011, simplified). 
archaeological evidence collected as part of the multidisciplinary Sealinks Project (funded by the European Research Council). Sealinks has undertaken field investigations in eastern Africa in order to examine the emergence and impact of early trading networks across the Indian Ocean (Fuller \& Boivin 2009; Fuller et al., 2011, 2014; Boivin et al., 2012, 2013, 2014; Helm et al. 2012; Shipton et al., 2013; Crowther et al., 2014a,b).

Kuumbi Cave is well suited for studying island speleogenesis since, a) its evolution can be constrained plausibly in a late Quaternary timeframe and, b) archaeological stratigraphy provides a means for dating some of the geomorphic events that reshaped the cave and its wider landscape.

\section{Discovery, archaeological significance and history of research}

Kuumbi Cave (S 6²1'40"; E 39³2'33') is situated in the Jambiani district, on Zanzibar's eastern coast. The cave was first reported as an archaeological site in 2004, by Dar es Salaam archaeologist Felix Chami, who was guided there by Jambiani residents (Chami, 2009). Successive archaeological excavations, by the universities of Dar es Salaam, Uppsala and, in 2010-2012, Oxford, have demonstrated a long history of human presence from the Late Pleistocene to the present (Sinclair et al., 2006; Chami, 2009; Shipton et al., in press).

Kuumbi's archaeological record may be crucial for documenting socioeconomic transitions in the East African littoral in early, pre-Islamic times. For this reason, Kuumbi Cave was one of the main foci of the Sealinks Project. Alongside archaeological excavation, the project undertook topographical/ geomorphological mapping and geoarchaeological fieldwork, with the following objectives: (1) to reconstruct the geomorphic evolution of the cave and its wider landscape; (2) to identify processes of sediment deposition, especially during periods of human presence, and postdepositional change that may have affected the integrity of the archaeological record; and, (3) to sample cave sediments for geoarchaeological and other palaeoenvironmental analyses.

\section{GEOLOGICAL AND GEOMORPHIC SETTING}

The island of Zanzibar, separated from the East African mainland by a narrow, fault-controlled shallow strait (ca. $-30 \mathrm{~m}$ in its shallower parts), originated from block faulting and differential uplift of the Neogene Ruvu-Rufuzi Delta, perhaps the largest deltaic depocenter in Neogene East Africa (Kent et al., 1971; Fig. 1). The axial parts of the island consist of Lower Miocene siliciclastics (channel conglomerates and sandstones; interchannel muds and marls), interdigitated and fringed with various Miocene limestones (grainstones, framestones). Underlying these there must be earlier, Mesozoic and Palaeozoic (Cretaceous, Jurassic, Karoo) sediments, similar to those cropping out in the mainland littoral, and, even deeper, Precambrian crystalline basement (cf. Mpanda, 1997).
Miocene sediments are overlain by extensive Pleistocene limestones ("Azania Series": Stockley, 1928) and Late Pleistocene-Holocene siliciclastics (aeolian sands, fluvial sands and gravel, colluvia from the reworking of Miocene sediments, etc.) and red latosols. Zanzibar is girdled by a living coral reef and shallow back-reef, with lagoons, platforms, sandy beaches and mangroves (Arthurton, 2003; Punwong et al., 2013a,b).

Pleistocene limestone of the 'Azania Series' extends over the entire region of central-eastern Zanzibar, from ca. $+30 \mathrm{~m}$ to below present sea level (Fig. 1). This heterogeneous lithostratigraphic unit comprises several limestone facies, deposited in various innershelf environments (reef framestones; reef slope breccia; backreef packstones/wackestones; shoal and beach grainstones, etc.). Azania Series limestone hosts numerous caves, solution pipes and collapse dolines (Fig. 1).

Miocene and Pleistocene sediments are cut by kilometre-long, shoreward-dipping normal faults parallel to the island's morphological strike (N-S to NNW-SSE: Fig. 1). Faulting and jointing of Pleistocene (including inferred Late Pleistocene) limestone suggests that Zanzibar (and its adjacent islands and continental coast) remains tectonically active.

\section{The cave in its landscape}

Kuumbi Cave is situated about $3 \mathrm{~km}$ from the Jambiani shore, on Zanzibar's eastern coast (Figs. $1,2)$. It is one of several caves underneath a marine terrace at +24-27 m (here termed the '25 m terrace') - the highest of a flight of (five?) marine terraces on Pleistocene Azania Limestone (Fig. 2). Limestone exposed on the Kuumbi Cave walls and the overcave terrace is mainly bivalve-gastropod packstone/ grainstone with high mouldic porosity (Fig. 3). This facies probably originated in a back-reef setting.

Kuumbi opens to the surface via a large collapse doline and several metre-sized, vertical gaping chasms, some with solution-smoothened inner surfaces (Fig. 3). Around the cave entrance, the landscape is a sacred grove: Kuumbi is a sacred site for the local community, and a strong taboo prohibits tree felling around it (Chami, 2009). Further away, overgrown fields, seemingly abandoned drystone walls and a few fields under cultivation evidence that the overcave terrace is part of an old agricultural landscape.

At field observation scale, relief on the overcave surface does not exceed ca. 1.5-2.5 m. Large parts of this surface are devoid of soil cover; elsewhere it is covered with loose, angular regolith or, where woodland is present (e.g. grove around the cave entrances, overgrown fields), by a thin $(\leq 60 \mathrm{~cm})$, dark, redzina-type soil (Fig. 3).

Vestiges of an earlier, cemented weathering mantle are also present on the $25 \mathrm{~m}$ terrace, in the form of metre-sized, heavily karstified bodies of reddish, clast- to matrix-supported breccia (Fig. 3). This deposit testifies to the development of regolith/soil cover under quite different past (Late Pleistocene?) climatic conditions, and the subsequent denudation of the terrace. 

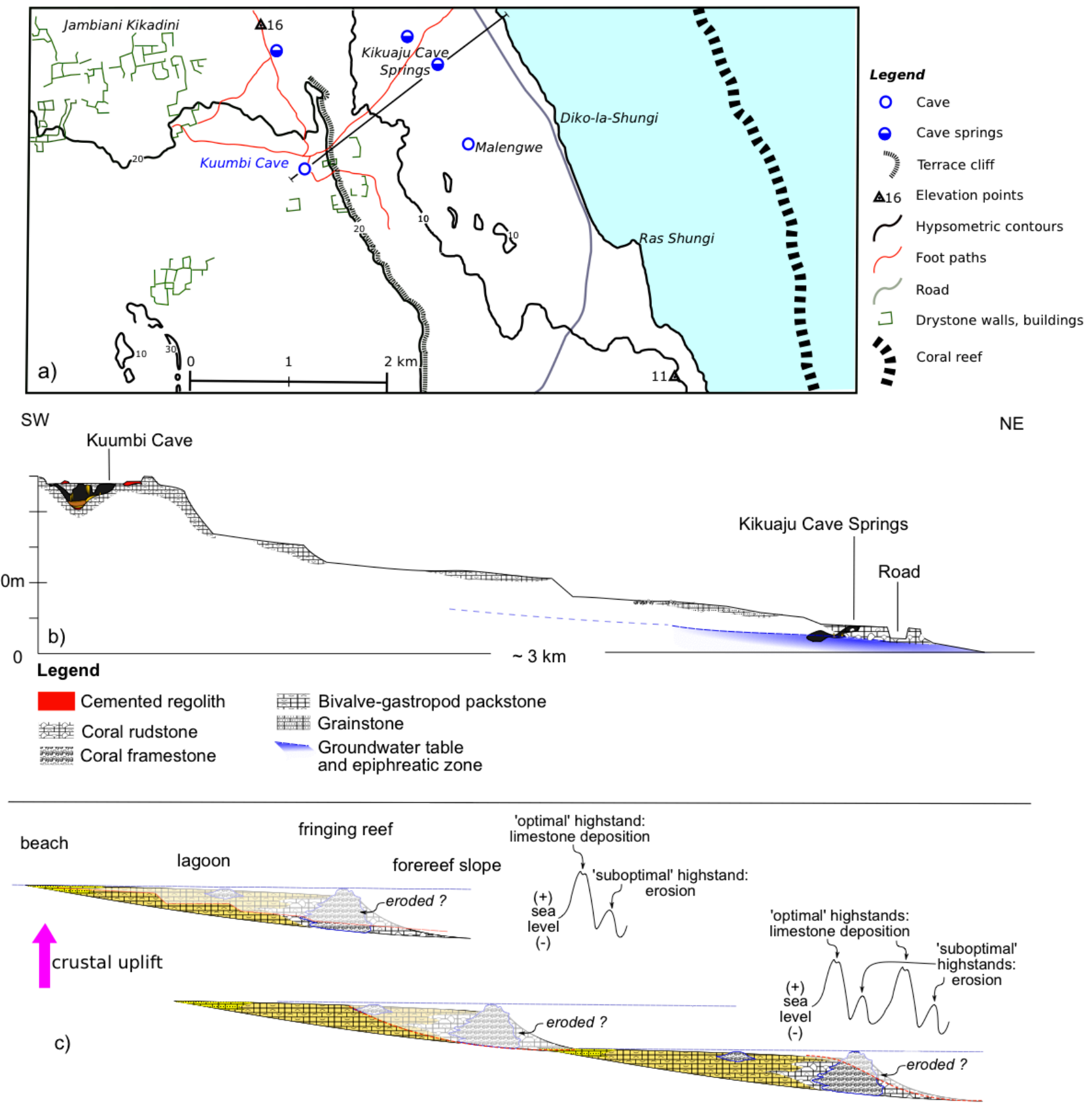

Fig. 2. a) Kuumbi and other caves of the Jambiani coast; b) Schematic geological section from Kuumbi Cave to the shore (not in scale); c) Interpretation of observed lithologies and landforms as resulting from at least two glacioeustatic sea level cycles (see text).

Collapse chasms and caves in Kuumbi's immediate vicinity (Fig. 3) and the presence of caves at lower terrace levels (e.g. Kikuaju Cave Springs: two caves flooded by brackish water; Fig. 4) suggest that Kuumbi Cave is part of a host of karstic cavities that perforate Azania Limestone from (below ?) present sea level to ca. $+25 \mathrm{~m}$.

\section{The Jambiani terrace flight}

Like other limestone terraces on the East African coast, from Somalia to Mozambique, the Azania Limestone and its terraces are thought to be Mid- to Late Pleistocene in age. Earlier workers (Arthurton et al., 1999; Arthurton, 2003) have correlated the Azania limestone with one or more substages of the Last Interglacial (MIS 5). To our knowledge, nonetheless, no absolute dates for this, or other upper Quaternary limestones in Zanzibar or the Tanzanian mainland, are available. Potentially correlative upper Quaternary limestones in coastal Kenya have yielded dates from $240,000(+70,000 /-40,000) \mathrm{BP}\left({ }^{230} \mathrm{Th} /{ }^{234} \mathrm{U}\right.$ date on coral: Battistini, 1977) to ca. $21-40,000 \mathrm{BP}\left({ }^{14} \mathrm{C}\right.$ dates on coral: Oosterom, 1988).

A date of ca. 44,000 +1900/-1500 BP $\left({ }^{14} \mathrm{C}-\right.$ uncalibrated) from siliciclastic sediments underlying the $25 \mathrm{~m}$ terrace in Lindi Bay, southern Tanzania may suggest that parts of the Tanzanian coast have undergone very rapid late Quaternary uplift (Reuter et al., 2010). This date, however, is close to the range limit of radiocarbon dating. In addition, lithological and tectonic differences between the Jambiani and the Lindi Bay coasts (the latter is situated on a major 

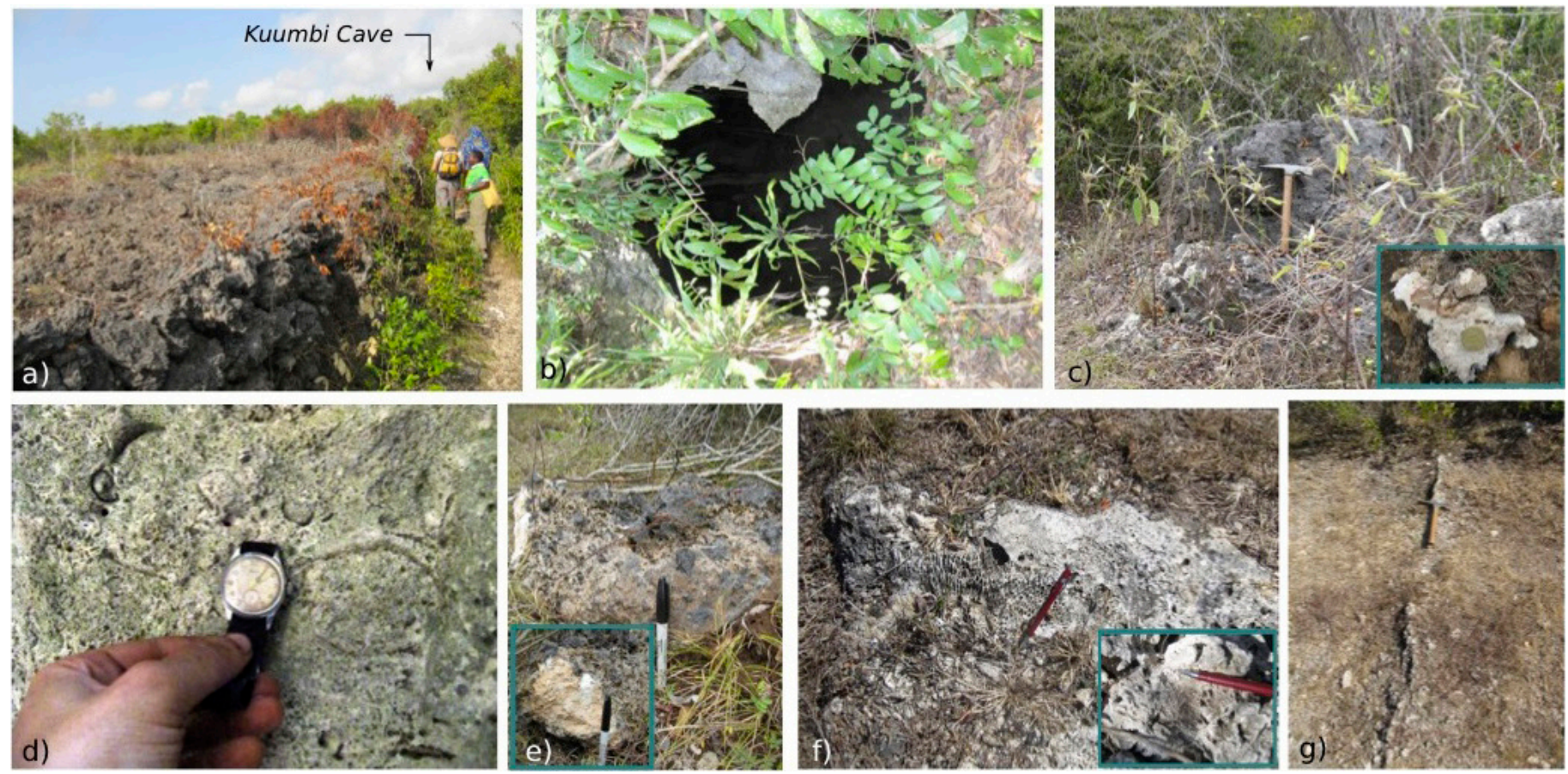

Fig. 3. Landscape, bedrock lithologies and palaeosols around Kuumbi Cave. a) On approach to Kuumbi Cave, looking west (inland): Small plots enclosed with drystone walls. The cave is situated in the grove in the background; b) A collapse opening on the $25 \mathrm{~m}$ terrace provides a window to another underground chamber, a few metres south of Kuumbi; c) 'Older Azania Limestone' underlying the $25 \mathrm{~m}$ terrace: porous packstone/ grainstone with moulds of bivalves and gastropods. Inset: detail of freshly exposed rock surface. Hammer: $33 \mathrm{~cm}$; d) The same limestone on the Kuumbi Cave wall. Note selective dissolution of marine molluscs and other skeletal grains (mouldic porosity). The green colour is due to microbial/ algal colonisation of the cave walls. Wristwatch diameter: $33 \mathrm{~mm}$; e) Vestiges of karstified regolith on the $25 \mathrm{~m}$ terrace, about $500 \mathrm{~m}$ NNE of the cave entrance. Inset: Freshly exposed surface of the latter, showing poor sorting of angular, corroded limestone clasts; $f$ ) In situ coral reef in

'Younger Azania Limestone', about 1.5 km NNE of Kuumbi Cave. Inset: Small polyp stony coral colony on the same reef; g) NNW-SSE striking joint (parallel to hammer handle) cutting 'Younger Azania Limestone' (Last Interglacial?) on the lower, $\leq 12 \mathrm{~m}$ terraces.
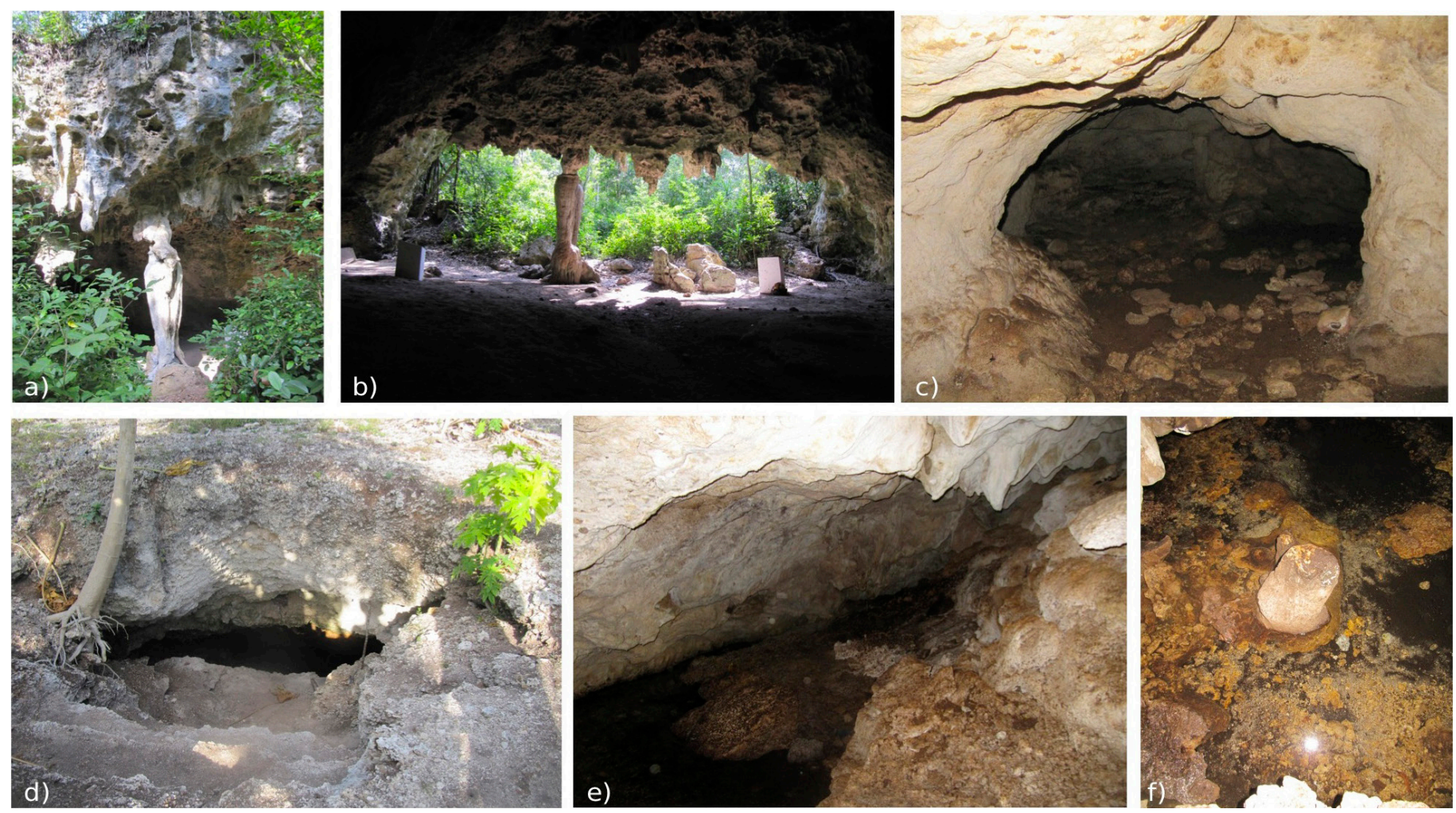

Fig. 4. Caves of the Jambiani karst. a) Looking down the vegetated talus slope of the NE entrance to Kuumbi Cave; b) Kuumbi Cave entrance, with speleothem column, truncated stalactites and roof fall blocks. The concrete pedestals mark earlier excavations by the University of Dar es Salaam. Looking out from Chamber $A$; c) Low-ceilinged alcove in Kuumbi Cave. Note cusps on the walls and speleothem rubble on the floor; $d$ ) Entrance to Kikuaju A cave spring, on the $\leq 12 \mathrm{~m}$ terrace(s); e) Inside Kikuaju A cave spring: cusps and bedrock pendants on the ceiling and speleothems on the sloping floor (right hand side); f) A weathered stalagmite, partly submerged in brackish water in Kikuaju A (torch reflection marks the water surface, which corresponds to the tidal sea level. Note the development of a thin ledge around the stalagmite. 
fracture zone within the Rowuma Microplate: Nicholas et al., 2007; Reuter et al., 2010), render correlation of the $25 \mathrm{~m}$ terrace in Jambiani with this relatively late date untenable.

Evidence from a limited survey from ca. $500 \mathrm{~m}$ west of Kuumbi Cave to the shore is summarised in Fig. 2. This evidence is inconclusive: very limited drainage incision across the terrace flight, dense, often impenetrable vegetation, and the ubiquitous drystone walls around fields cultivated and abandoned prevented the discovery of tell-tale outcrops. The following considerations, however, lend some tenuous support to our interpretation of the Azania Limestone as comprising at least two distinct lithostratigraphic units (Fig. 2):

1) The $25 \mathrm{~m}$ terrace preserves remains of regolith/ palaeosol (Fig. 3). No similar palaeosol was identified on the lower terrace(s).

2) Overall, limestone of the lower $(\leq 12 \mathrm{~m})$ terraces appears less intensively karstified and denuded than that of the $25 \mathrm{~m}$ terrace (e.g. caves under the lower terraces have fewer/smaller openings to the surface). Effects of lithological composition notwithstanding (lower limestones contain reef and reef slope facies with very porous coral fragments and in situ coral colonies: Figs. 3, 4), it is possible that differences in intensity of karstification and surface denudation reflect the older age of the $25 \mathrm{~m}$ terrace limestone.

3) Two 'sets' (lithostratigraphic units) of 'Azanian Series' coral limestone, one at ca. $12 \mathrm{~m}$ and one at ca. $7.5 \mathrm{~m}$ were distinguished by Stockley (1928) in neighbouring Pemba Island (Fig. 1) - an assertion confirmed by later geologists (Caswell, 1956). It is likely that these two limestone units correlate with principal terrace levels (25 and $\leq 12 \mathrm{~m}$ ) in eastern Zanzibar. Altitudinal differences between limestone units across the two islands are small enough to be attributable to field measurement uncertainties and/ or neotectonic faulting or differential uplift.

4) Terraced limestones in coastal Kenya (Fig. 1) are also resolved into at least two stratigraphic units (Braithwaite, 1984; Oosterom, 1988; Abuodha, 2004). The earlier/higher of these units, associated with the ca. $30 \mathrm{~m}$ terrace (Abuodha, 2004), is mainly a 'back reef' facies (Braithwaite, 1984), broadly comparable with the limestone of the $25 \mathrm{~m}$ terrace in eastern Zanzibar.

We thus interpret the observed surface geology as a terrace flight eroded on at least two stratigraphically distinct limestone units (sequences), each correlated with a sea level highstand: the 'Older Azania Limestone' hosting Kuumbi and other caves underneath the $25 \mathrm{~m}$ terrace; the 'Younger Azania Limestone', hosting the two Kikuaju cave springs and, reportedly, other caves underneath the $\leq 12 \mathrm{~m}$ terraces. These sequences are separated by (inferred) erosional unconformities / disconformities, corresponding to marine regressions and sea level lowstands.

In this scenario, each of the two sequences corresponds to orbital-scale sea level cycles, correlative with main MIS stages. The time of deposition of the Older Azania Limestone is unknown: it may date from the penultimate interglacial, MIS 7 , to earlier Pleistocene, or (less likely) even earlier,
Neogene highstands. Chronological uncertainties notwithstanding, our working hypothesis correlates the Older and Younger Azania limestones with the (composite) MIS 7 and MIS 5, respectively. The highest/earliest terraces on each limestone sequence date from their depositional highstands: MIS 7 for the $25 \mathrm{~m}$ terrace; MIS 5 (5e?) for the 10-12 m terrace, respectively (Fig. 2). It is probable that higher-order sea level cyclicity during each of these highstands resulted in erosion of marine terraces, deposition of higher-order carbonate units and/or reoccupation of earlier terrace levels. Although these events are unresolved, some of the relatively closely-spaced and poorly defined terraces below ca. $12 \mathrm{~m}$ may thus have resulted from erosion in MIS 5 substages.

Assuming that present terrace surfaces are a (very) rough approximation of sea level at the time of their formation (inner shelf relief is no more than ca. $10 \mathrm{~m}$ in present day Zanzibar: cf. Arthurton, 2003), taking -15 to $-5 \mathrm{~m}$ and +4 to $+6 \mathrm{~m}$ as the highest eustatic sea levels in MIS 7 and MIS 5 (5e), respectively (cf. Siddall et al., 2006), and factoring in about 8.75 and $16.8 \mathrm{~m}$ of denudation for the lower and higher terraces, respectively (based on the indicative denudation rate of eogenetic limestones: ca. $70 \mathrm{~mm} / 1000$ yrs - Jennings, 1985 - and consistent with evidence from other tropical carbonate islands: e.g. Miklavic et al., 2012), this correlation suggests late Quaternary crustal uplift at the rates of 0.10 to $0.20 \mathrm{~mm} / \mathrm{yr}$. These poorly constrained and purely indicative - uplift rates are of a similar order of magnitude with the rate of $0.1 \mathrm{~mm} / \mathrm{yr}$ calculated independently for parts of coastal (Oosterom, 1988) and inland Kenya (Veldkamp et al., 2007). The later part of the Quaternary, perhaps since 250,000 BP, may, therefore, be a plausible timeframe for the formation of Jambiani terraces and their underlying caves.

\section{CAVE MORPHOLOGY}

Kuumbi Cave comprises two large chambers and several smaller side alcoves, anastomosing and/or appending into progressively narrowing, low-ceilinged cavities, often developed around bedrock pillars. In plan, morphology is that of a spongework maze (sensu Palmer, 2011: 9). Some of the peripheral cavities, too narrow to explore, may link Kuumbi Cave with other karstic chambers (Figs. 5, 6).

The cave is accessed from two entrances: a large collapse doline (surface extent ca. $1 / 2$ of Kuumbi's largest underground chamber) in the $\mathrm{NE}$, and a smaller collapse doline in the SW. Four other circular openings, resulting from collapse of the solutionally undermined cave ceiling, also link the cave with the surface.

The two main chambers are oriented NW-SE and NESW (Fig. 5), perpendicular and parallel, respectively, to the $25 \mathrm{~m}$ terrace cliff (about $60 \mathrm{~m}$ east of the cave entrance: Fig. 1). Smaller alcoves and tubes, although more variable in orientation, also conform with these two principal strikes. These directions coincide with the strikes of - rare - joints in the cave walls and in Pleistocene limestone outcrops further from the cave 
a)

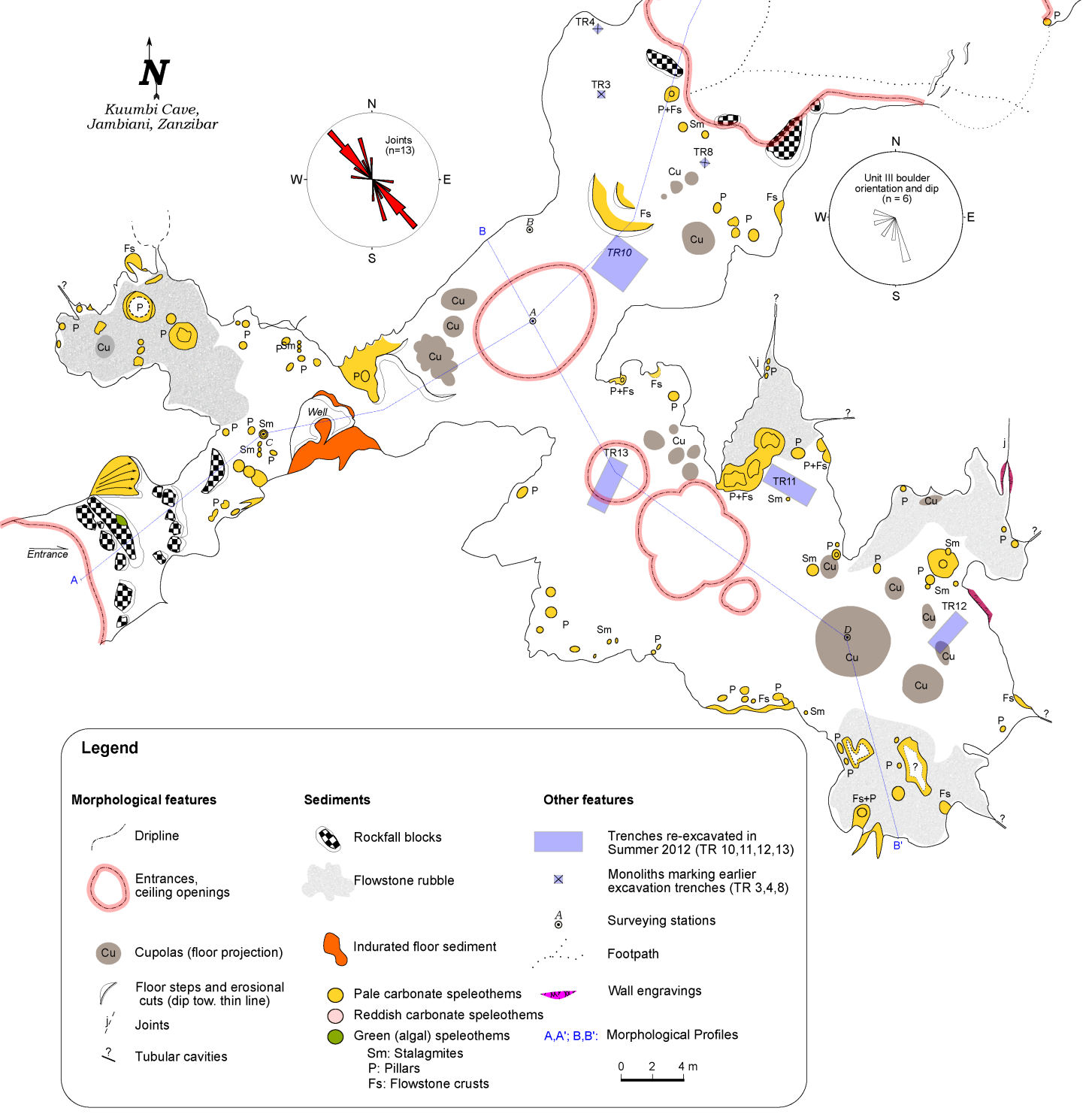

b) $A(S W)$

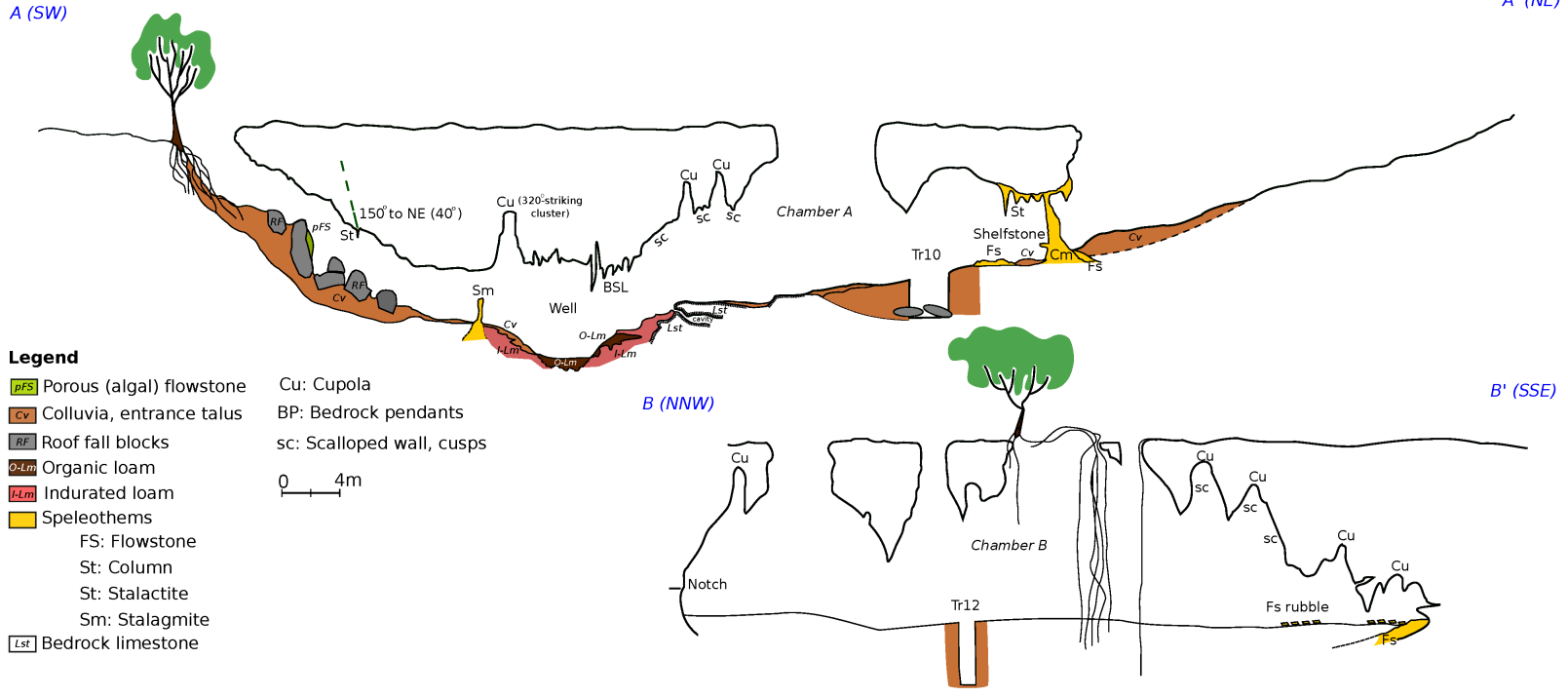

Fig. 5. Geomorphological plan (a), and profiles (b) of Kuumbi Cave. 
(Figs. 3, 5). The coincidence between joint strikes and the orientation of regional tectonic structures (NNWSSE NNE-SSW faults that control continental shelf morphology across the Zanzibar Archipelago: Mpanda, 1997; Chorowicz, 2005; Nicholas et al., 2007; Fig. 1), suggest that these joints are of neotectonic origin.

In cross section, the exposed part of Kuumbi Cave is shaped like an open U. Cave profile is modified by steep rock fall/talus cones at the two cave entrances (Fig. 5) and by finer grained inner-cave sediments. These obscure the geometry of the lower parts of the cave.

Ledges and notches (from 0.4 to $1.7 \mathrm{~m}$ above cave floor) and a shallow, partly buried rockshelter about $2 \mathrm{~m}$ below the overcave terrace (Fig. 5) manifest a succession of karstic dissolution levels. Metresized cavities under floor sediment (Fig. 5) suggest that karstic dissolution extended below the detrital sediment/bedrock interface.

In Chamber A, the cave floor dips from each entrance to the 'cave well', a ca. $2.5 \mathrm{~m}$-deep depression where water pools in the rainy season, probably as a result of vadose water perching. At the time of visit (late August - early September 2012) the well was dry, but the muddy sediment of its floor was moist. The 'cave well' appears to have been enlarged artificially, probably to facilitate procurement of drinking water.

Entrances and ceiling openings permit sunlight and air circulation in the main cave chambers and provide entry points for rainwater, surface runoff and
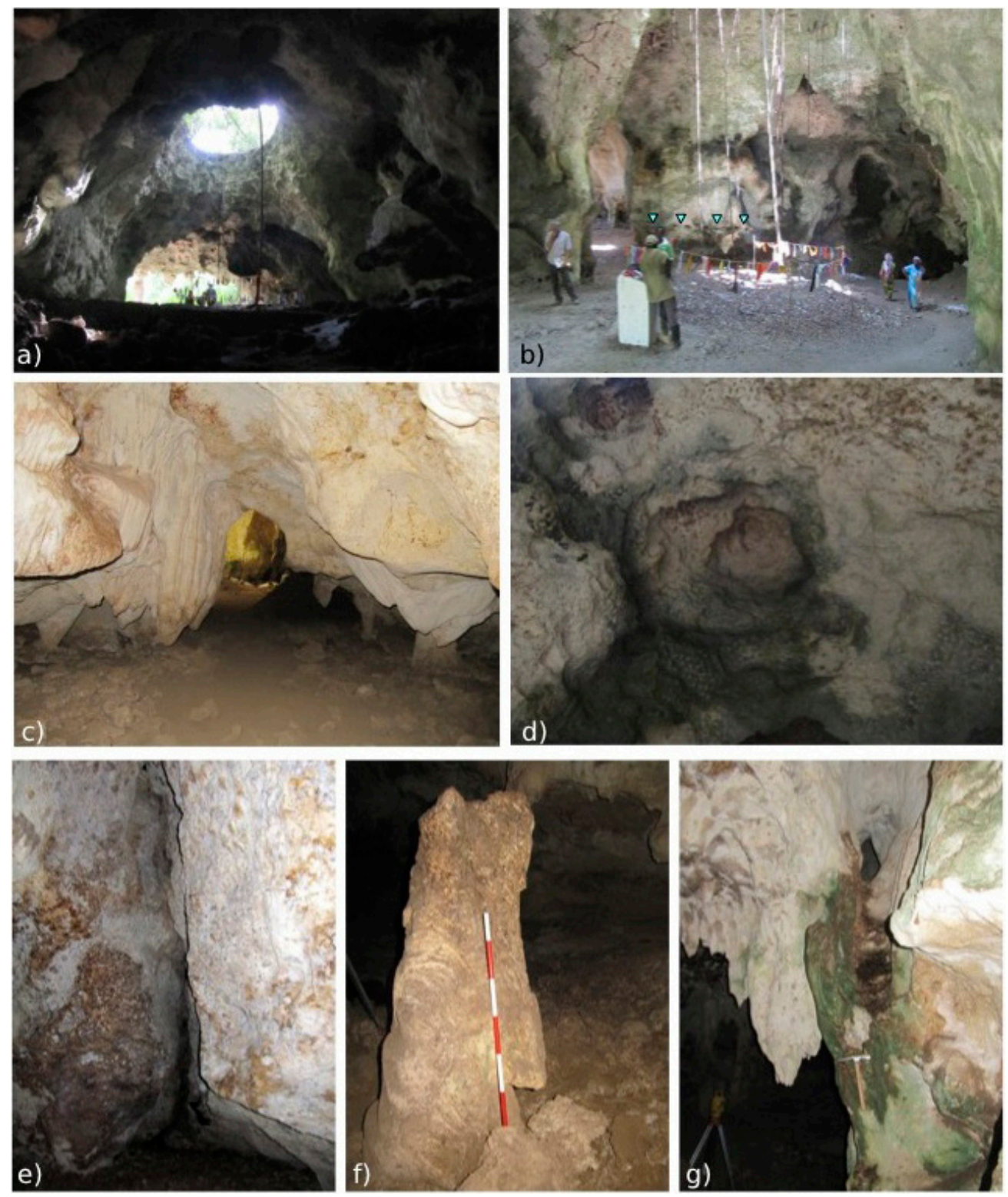

Fig. 6. Solutional forms and speleothems in Kuumbi Cave. a) Chamber A, viewed from the Well. Stepped floor in the foreground was formed on indurated sediment; b) Chamber A, looking towards the Well (behind people on the right). Triangles mark notch at ca. $170 \mathrm{~cm}$ above present floor level. Another notch is present a few centimetres above; c) Side alcove off Chamber B. Detrital sediments bury earlier speleothems and erosional relief (bedrock pendants). The floor rubble is mainly fragmented carbonate crust, possibly correlative with a later (late Holocene?) phase of $\mathrm{CaCO}_{3}$ deposition (see text). Note the apse and the horizontal ceiling on the left side, seemingly correlative with the notch in Fig. 6b; d) Small cupola and cusps on the cave ceiling. The rusty-brown spots are speleothems, probably of high humic acid content; e) Narrow vertical cavity off Chamber B, developed along N-S-trending joint. Human-made engravings (not visible here) are present on the iron oxide-stained cavity walls; f) Heavily weathered stalagmite; Chamber A; g) Corrosion of speleothems (above hammer), probably due to guano from a bat-roosting cupola overhead. SW cave entrance. 
sediment washed in from the surface. These openings thus impart an environmentally liminal character, akin to that of a cave entrance, or a large rockshelter. These 'open cave' conditions contrast with those in smaller, low-ceilinged alcoves (Fig. 6). The latter, which seem to host most of the cave's resident bats, were perceptibly more humid and warmer at the time of visit, with a somewhat stagnant atmosphere, probably enriched in $\mathrm{CO}_{2}$ from decomposition of organic matter (mainly bat guano) on their floor, and condensation droplets on the ceiling. It was in these alcoves that some active water seepage was noted, but there was little correlation between this and speleothems: most of the well-developed stalactites appeared inactive.

\section{Small/medium-scale forms \\ Cusps}

Decimetre-scale, shallow, concave cavities are ubiquitous on the walls and ceilings of those parts of the cave that have not been modified by later collapse. Cusps are present as juxtaposed and crosscutting clusters of cavities, distributed over the entire exposed limestone surface (Fig. 6), locally in association with bedrock pendants and pillars (see below). They resemble scallops, but appear to be nondirectional: elliptical rather than shallowing-outwards in cross section.

At Kuumbi Cave, cusps and alcoves appear to be outcomes of the same dissolutional process: cusps appear to have formed at the dissolution front as lowceiling alcoves became enlarged. We thus interpret cusps in Kuumbi as "primary dissolution features" (sensu Frank et al., 1998). Cusps have been reported from many tropical and temperate flank margin caves (Frank et al., 1998; Mylroie et al., 2001, 2008; Myrloie $\&$ Mylroie, 2009); there they have been attributed to slow phreatic dissolution.

\section{Links and tapering tubules}

Oval-shaped, generally smooth-walled cavities $(<10-100 \mathrm{~cm})$, that often follow dominant orientations of larger cave passages and joints, link side alcoves of the cave, lead to other, currently inaccessible chambers, or appear to continue for some length in the bedrock (Fig. 5). These tubes are interpreted as phreatic in origin, suggesting that Kuumbi Cave was water-filled in earlier stages of its evolution.

\section{Solution cavities ('cupolas')}

Large (up to $1.5 \mathrm{~m}$ maximum diameter; up to 2.5-3 m deep), cylindrical to gently tapering up, vertical cavities are very frequent on the cave ceiling (Figs. 5, 6). Cupolas (also termed 'bell holes') are often concentrated in linear clusters, or as groups of randomly juxtaposed, cross-cutting pockets, often in the axial part of much broader, domed sections of the ceiling (Fig. 5). These landforms are favourite batroosting sites.

Their vertical development and narrowing-up crosssection suggest that cupolas were formed from upward dissolution. This process may have operated in a wide range of underground conditions, so cupola genesis is subject to debate (c.f. Osborne, 2004; Birmingham et al., 2011 for overviews). Proposed speleogenetic contexts include phreatic dissolution (Sweeting, 1972; Trudgill, 1985; Sancho et al., 2004; Piccini et al., 2007), possibly at the site of local convection cells in conditions of "sluggish rising forced flow" (with "less dense and more aggressive water" located in the upper parts of these cells: Klimchouk, 2009); pressure increase and dissolution above pooled groundwater (Lismonde, 2000), to vadose condensation corrosion, mediated by roosting bats (Lundberg \& McFarlane, 2009).

At Kuumbi, where the groundwater table is shallow and bats abound, cupolas may have resulted from any of these processes. The close spatial association of cupolas with other phreatic dissolution landforms (e.g. bedrock pendants, cusps), nonetheless, suggests that these features had a phreatic (to epiphreatic) origin. Bat roosting probably modified them, but it appears unlikely to have formed them.

Cupolas are deep enough to undermine the cave ceiling, especially in parts of the cave where they cluster together. Circular openings through the cave ceiling to the surface probably resulted from ceiling collapse following denudation of the overcave surface (c.f. Birmingham et al., 2011). These openings probably concentrated at the location of cupola clusters.

\section{Bedrock pendants}

Sharp-edged pendants of bedrock limestone remnants of bedrock that escaped dissolution - are present in side alcoves (Fig. 6). Bedrock pendants are thought to result from pervasive, mainly upwarddirected dissolution in phreatic (Sweeting, 1972; Klimchouk, 2009) and/or paragenetic (when much of the cave chamber was filled with sediment) conditions (Farrant \& Smart, 2011).

In Kuumbi Cave, there is no (direct) evidence for former occlusion of chambers by sediment, whereas bedrock pendants are associated with a plethora of other, evidently phreatic meso/microforms. A paragenetic interpretation of bedrock pendants would produce an unduly complex narrative of cave evolution. We thus interpret these as phreatic landforms, resulting from upward dissolution by slowly circulating aggressive water.

\section{Wall notches}

One or two poorly expressed notch(es) are present on the southeastern wall of Chamber A, between 1.70-2.20 $\mathrm{m}$ above the sloping (present) cave floor (Figs. 5, 6). Parts of these discontinuous notch(es) present as a singular embayment; other parts present as a series of closely spaced, decimetre-sized cavities concentrated at the same level.

These notches appear to correspond approximately to the level of a flowstone shelf around a column underneath the present cave entrance, and, also, to the upper level of mammillate (subaqueous?) speleothems in Chamber B. These notches may mark one (or more) former groundwater table stillstand(s), but whether wall notching and speleothem deposition took place concurrently or, and more likely, in different phases of cave flooding by groundwater, cannot be confirmed on current evidence. 


\section{Floor cavities}

A low-ceilinged chamber $(\geq 2 \mathrm{~m})$ extends under the cave floor near the cave well. This chamber was dissolved in bedrock and indurated floor sediment, and is partly filled with organic mud similar to that deposited at the well (Fig. 5). Although the chamber dimensions and morphology could not be assessed (its opening is too narrow to enter), its presence hints at a complex succession of detrital deposition, cementation and dissolution phases.

A few metres from that chamber, also by the cave well, indurated detrital sediment is penetrated by a network of $<20$ to $60 \mathrm{~cm}$-deep solutional cavities and numerous smaller-scale pores, occluded by flowstone and later detrital deposits.

\section{Dissolution of speleothems}

At Trench KC12, underneath a cupola cluster, a carbonate floor crust is perforated by a network of decimetre-scale, irregular solutional cavities filled with organics and phosphate-rich, probably guanoderived mud (Fig. 7). Accelerated dissolution of the floor crust there was probably due to the low $\mathrm{pH}$ effluents generated by guano diagenesis. Guanoinduced pitting of speleothems, and their diagenetic alteration (to as yet unidentified phosphates?) is present on some stalagmites (Fig. 6).

Speleothem dissolution microforms occur elsewhere in the cave: cm-scale solution features resulted from aggressive water trickling over ledges solutional microrelief cuts across stalagmite lamina locally; larger, m-sized cavities and windows through stalactites and draperies may have resulted from condensation corrosion.

\section{KUUMBI CAVE SEDIMENTS: STRATIGRAPHY AND FACIES}

A stratigraphic synthesis of Kuumbi Cave, compiled from the three excavated trenches and several sediment exposures, is shown in Fig. 7. The cave stratigraphy, of thickness ranging from ca. 2.5 to $1.5 \mathrm{~m}$, is resolved into nine depositional units of detrital deposits and speleothems. Most of these units group together several stratigraphic contexts (sensu Harris, 1989) identified on excavation, and can be correlated across trenches, either within each chamber or cave-wide. These units are enumerated with Roman numerals (with a trench identifier where appropriate). Two depositional units which were not exposed in the excavated trenches, and whose stratigraphic position was inferred tentatively from lateral relationships, are listed with descriptive abbreviations (units St: multiphase speleothems and IL: indurated loams). Radiocarbon and OSL dates on charcoal, bone and ceramics collected during the SEALINKS excavation from the near-entrance Trench KC10 are shown in Fig. 8 (see Shipton et al. (in press) for a discussion of dating methodologies and chronostratigraphic interpretation).

The basal sediments of Kuumbi Cave include a red siltstone of unknown age (Unit I) and altered carbonate crusts (Unit II), locally with extensive iron mottling (e.g. Trench KC11).
Kuumbi's speleothems are grouped together in Unit St. These include various forms, from floor deposits, with some very large stalagmites and columns and a flowstone cascade (near the SW cave entrance), to straw and conical stalactites and various types of globular speleothem. Mammillate speleothems that may have been deposited underwater or from supersaturated films(?) are also present locally, largely buried under later detrital sediment (Fig. 9). The rusty brown colour of some speleothems on the cave ceiling (e.g. Fig. 6) is probably due to their high content in soil-derived humic acids (van Beynen et al., 2001). Porous flowstone of algal-microbial origin is also present on roof-fall blocks near the SW cave entrance. This deposit evidently post-dates ceiling collapse and the opening of the entrance (Fig. 9).

Speleothem deposition was manifestly diachronous and multiphase, as suggested by the juxtaposition of several speleothem forms, and the interdigitation of flowstone and detrital sediment locally. The bulk of speleothem deposition appears to have predated detrital sedimentation, but there is evidence for late(?) Holocene resumption of carbonate deposition in the cave (see below). Chronological resolution of speleothem deposition requires further dating and field evidence.

\section{Cave entrance}

Metre-sized rounded boulders of bedrock limestone and speleothems by the NE cave entrance (Unit III ${ }^{\mathrm{TR} 10}$ ) may signal ceiling collapse linked to the formation of this entrance, probably in Late Pleistocene times. These boulders, evidently deposited as open-work breccia, were buried in reddish yellow pebbly loam (Unit IV TR10: contexts 1026-1025; Fig. 7) with Achatina spp. landsnails, sporadic fragments of marine molluscs, leopard, and relatively abundant small bovids and bat remains. Charcoal from this unit was dated to around 20,000 cal. BP (Fig. 8). This, and one earlier radiocarbon date of landsnail shell (21695 \pm 300 BP: Sinclair et al., 2006, which calibrates to around 25-26,000 cal. BP), suggest that this unit was deposited on the eve of the Last Glacial Maximum (LGM). This interboulder loam was probably deposited in a talus cone, with sediment supplied from the reworking of earlier soils/sediments on the overcave surface, perhaps in conditions of sparser vegetation and/or more pronounced rainfall seasonality on the approach to the LGM.

Unit V VR10 (contexts 1024-1018), above the latter (Fig. 7), is a dense accumulation of Achatina spp. landsnails, mingled with diverse mammal remains (predominantly small bovids; also bushpig, hyrax, small primates, and, significantly, larger taxa now extinct from Zanzibar: zebra, buffalo, waterbuck, reedbuck, bushbuck, bush duiker and possible Thomson's gazelle), small amounts of fish bone, marine molluscs (predominantly Nerita spp. and Lunella coronata), charcoal and lithics. Up to $11 \%$ of bones are burnt; remains of monkey, dwarf bovid and larger bovis are cutmarked. This deposit, dated to around 18,500-17,000 cal. BP (Fig. 8), is the earliest unequivocal indication of regular human presence in the cave (Shipton et al., in press). 

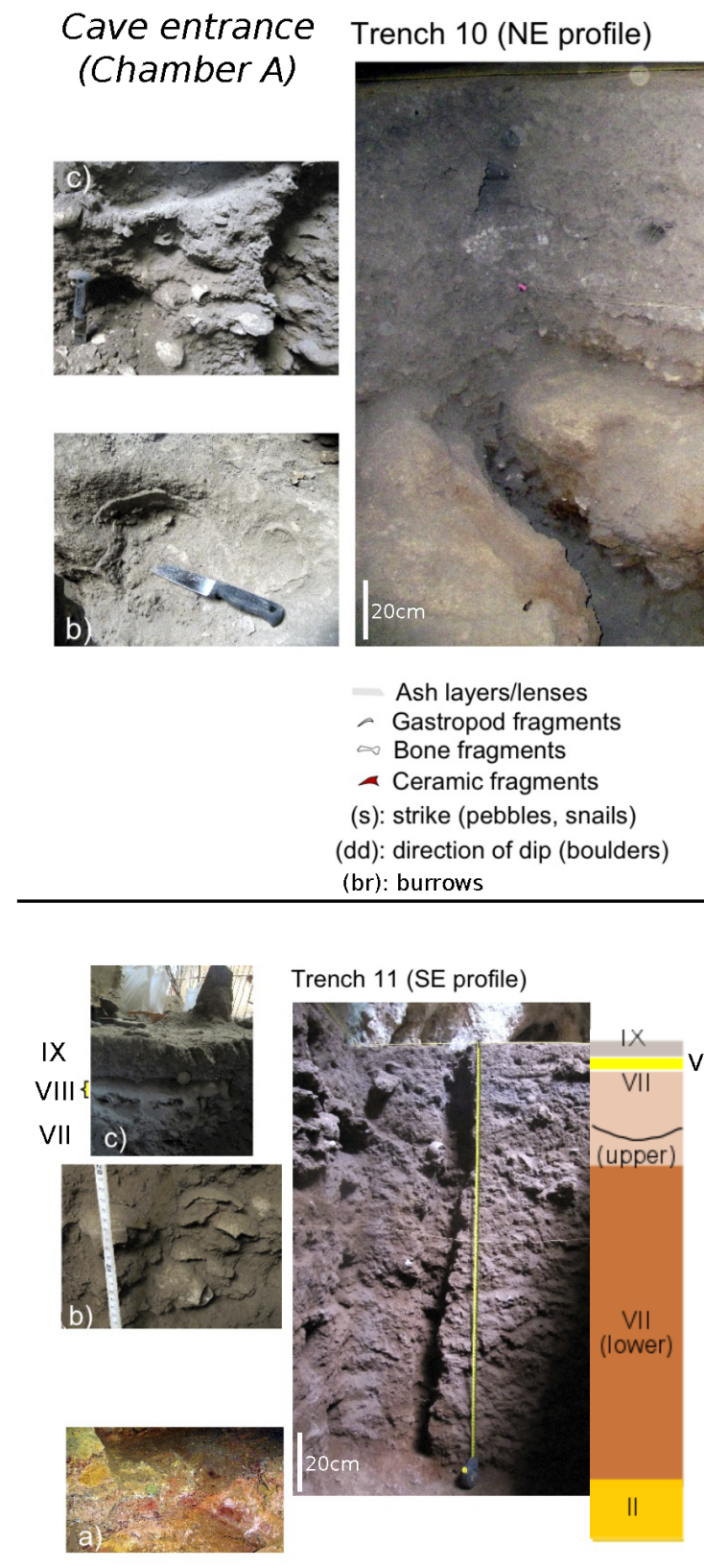

(br): burrows

Loose heterogeneous

shelly breccia

III Carbonate crust

Brown muddy loam

Carbonate crust
Heterogeneous

loam

Cemented

loam

Heterogeneous

breccia with snails,

bone, lintics,

ceramics (upper)

'Snail Apocalypse':

Achatina spp. snails, bone, lithics

Red silt with

landsnails

Boulders

Weathered carbonate crust

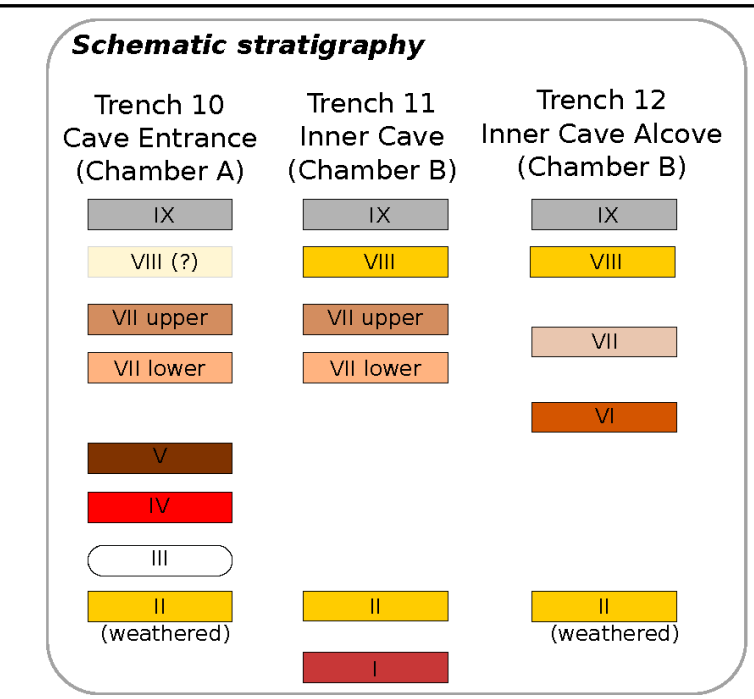

Trench 12 (NNW profile)

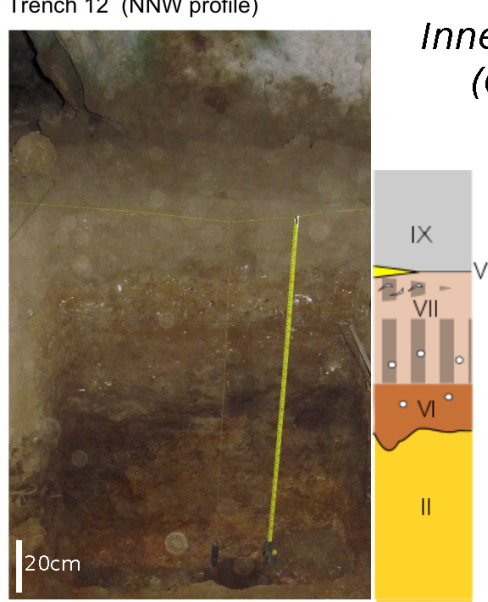

Inner Cave Alcove (Chamber B)

Heterogeneous shelly loam

IIII Carbonate crust

Heterogeneous shelly loam

Brown organic mud

Carbonate crust

Fig. 7. Cave floor stratigraphy in near-entrance (Trench 10: top) and inner cave settings (Trench 11: middle, Trench 12: bottom; Insert: schematic stratigraphic synthesis). I to IX: stratigraphic units (see text). Rose diagrams: clast orientation. Top: a) Heavily weathered, crumply carbonate crust (Unit II) underneath Unit III collapse boulders; b) Unit III boulder surface with flowstone encrustation; c) Landsnail (Achatina spp.), bone and ash accumulation marking the earliest unequivocal phase of human occupation: Unit V: ca. 18,500-17,000 cal. BP. Middle: a) Carbonate crust (Unit II) with Fe/Mn oxide intercalatations and mottling, consistent with waterlogging; b) Concentration of landsnail shell fragments in upper parts of Unit VII; c) Late(?) Holocene flowstone (Unit VIII) between detrital Unit VII and subrecent floor deposits (IX). This flowstone intercalation can be traced in the stub stalagmite at the background. Bottom: High organic content in lower Unit VI and neoformed (phosphatic?) nodules reflect bat guano inputs from an overhanging cupola. 


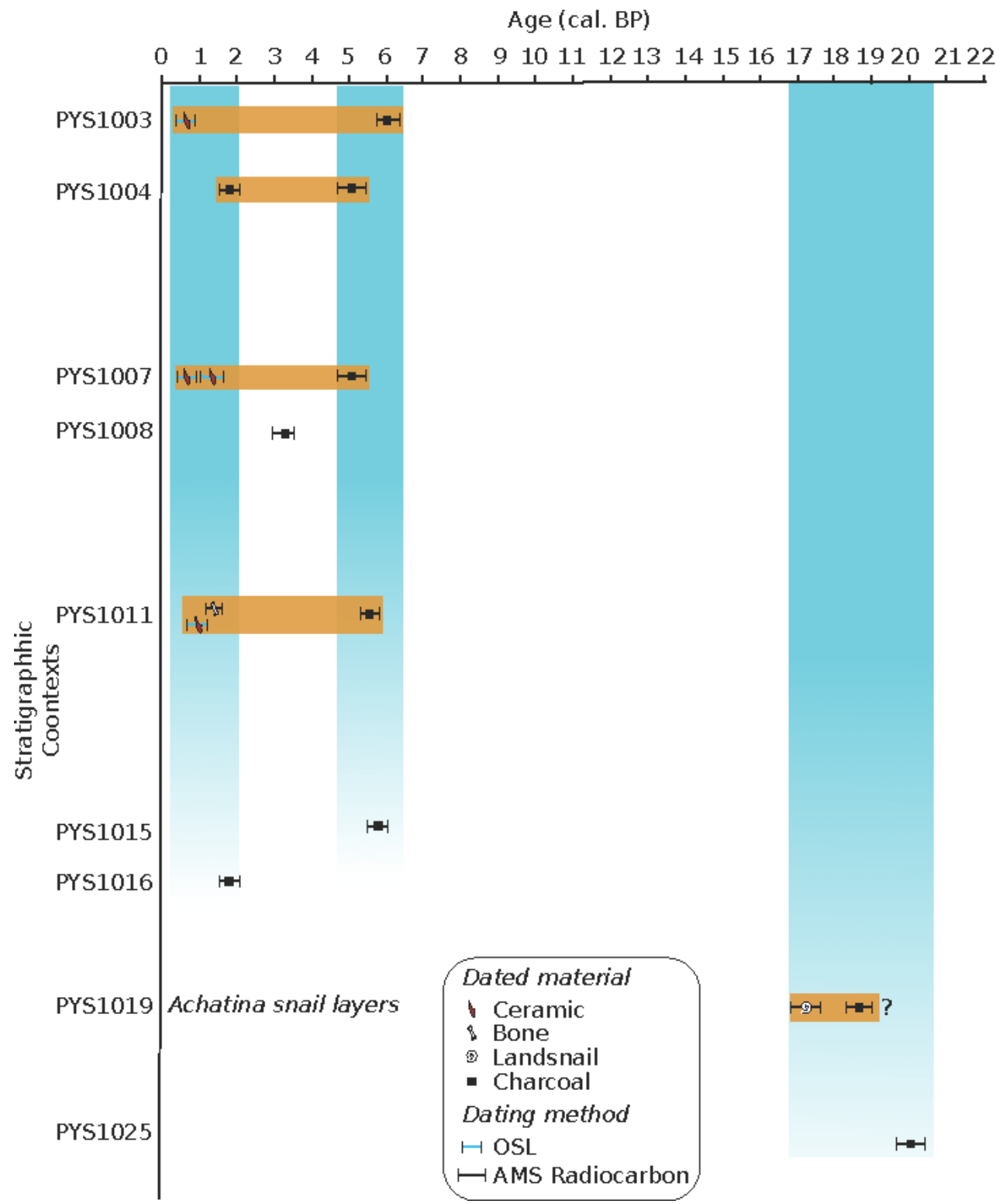

Fig. 8. AMS radiocarbon (SHCal13 calibration curve; $95.4 \%$ probability) and OSL dates from talus slope sediments near the entrance of Kuumbi Cave (Trench 10). Dates cluster in three time frames: Late Pleistocene (20,500 to 17,000 cal. BP, with unequivocal occupation deposits between 18,50017,000 cal. BP: Unit VTR10); mid-Holocene (6200-4800 cal. BP); and late Holocene (2000 to 600 cal. $\mathrm{BP}$ ) - both in Unit VIIT10. The youngest date cluster (on ceramics as well as on charcoal), records a phase of renewed late Holocene occupation. Mid-Holocene charcoal (of uncertain provenance) may have originated from fires on the overcave surface: evidence for increased fire frequency during a possible Mid-Holocene arid climatic phase has been inferred from elsewhere in Zanzibar (Unguja Ukuu: Pungwong et al., 2013b). In the Holocene part of stratigraphy (Unit VIITR10), incongruent dates from the same stratigraphic context and chronological inversions may have resulted from reworking of older, mid-Holocene charcoal into late Holocene occupation deposits by slope processes, bioturbation and human activity (for full discussion see Shipton et al. in press).

Very heterogeneous, poorly sorted loams with diverse human inputs (ash, charcoal, burned bone and shell, and sparse but diverse material culture, including lithics, worked bone and, in higher layers, ceramics) and occasional hearths and other palaeofloor deposits constitute the upper part of

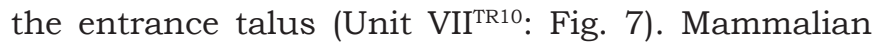
remains are abundant, with burned and cutmarked bones indicating anthropogenic origin of the faunal assemblage. Taxonomic diversity is high, with various marine molluscs, fish and (rare) turtle and sea urchin remains alongside various land mammals, reflecting the broad foraging spectrum of the cave's human occupants. Extinct taxa are present in the lower parts of the unit but decrease in relative frequency up- sequence, disappearing entirely in the higher layers. Fauna still found on Zanzibar (dwarf bovids - suni and blue duiker, suids, monkeys, hyrax, giant rat) are also common. Smaller taxa, perhaps unrelated to human occupation (bushbabies, bats, small rodents, reptiles), and carnivores (leopard, mongoose, civet) occur at low frequencies. Indications that carnivores had any role in the accumulation of the faunal assemblage are, nonetheless, lacking.

Radiocarbon (on charcoal and bone) and OSL (on ceramics) dates range from ca. 6000 to 600 BP (Fig. 8), perhaps indicating a long occupation hiatus between terminal Pleistocene and late Holocene (although people may have still inhabited other parts of the landscape around Kuumbi: Shipton et al., in press). 


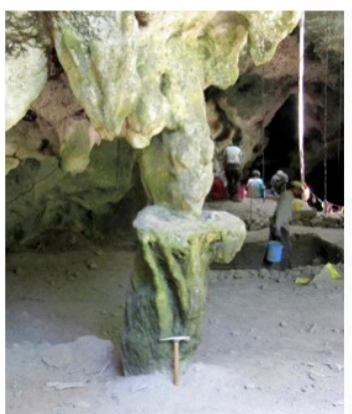

a)
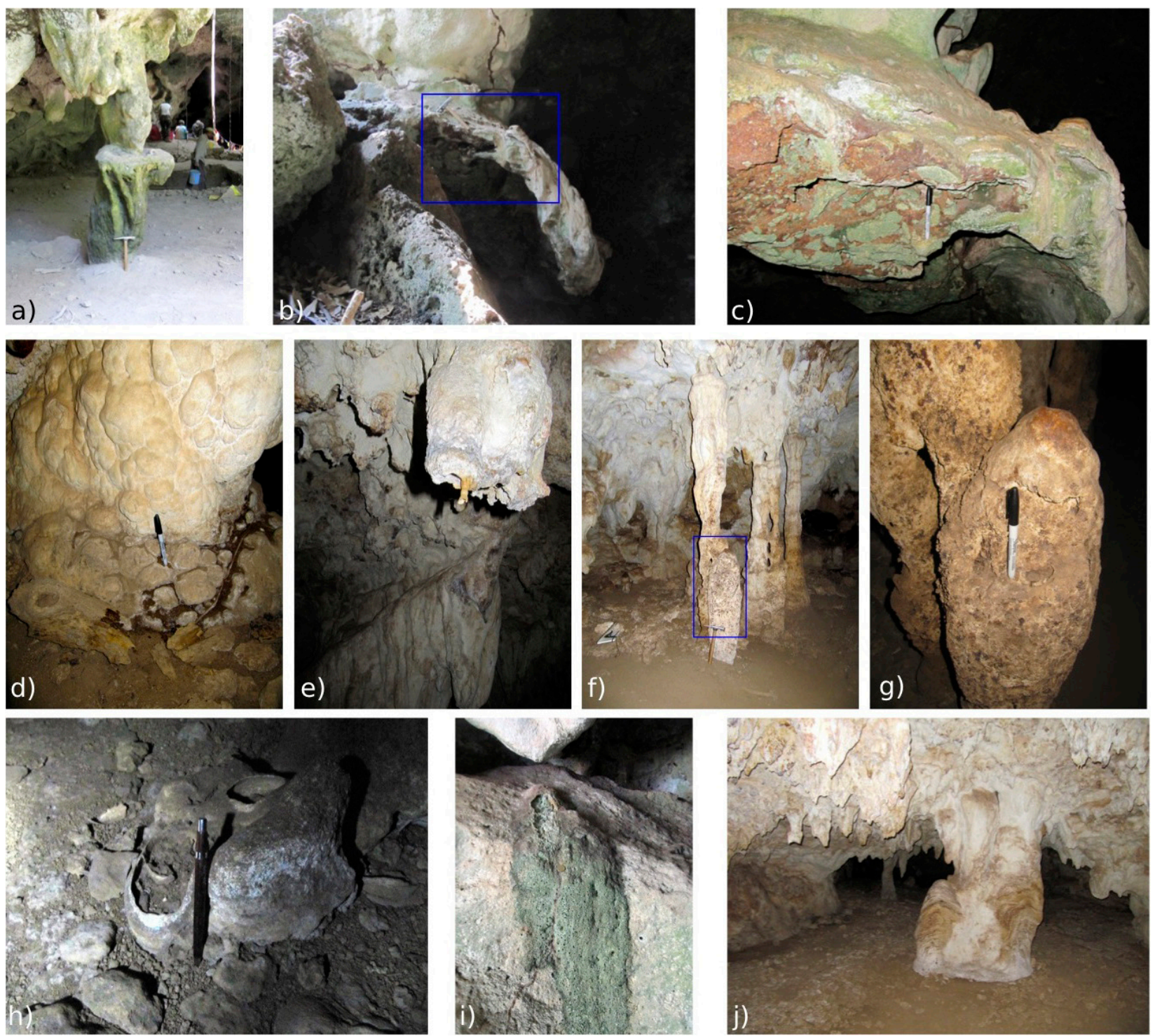

Fig. 9. Kuumbi Cave speleothems. a) Column at the NE entrance, with a shelfstone ledge, encrusted by later dripstone/flowstone, in the middle. The ledge, which differs from typical phreatic overgrowth speleothems (c.f. Tuccimei et al., 2010), indicates that vadose speleothem deposition was interrupted by at least one phase of partial submergence of the cave floor; b) Flowstone crust cascade, dipping towards the cave interior. SW entrance; c) Detail of the eroded surface of the same crust (frame in previous), and stubby stalagmite; d) Mammillate wall crusts. Alcove off Chamber B. Note postdepositional weathering (below pen); e) Renewed stalactite growth on weathered and broken, earlier generation stalactite. Alcove off Chamber A; f) Columns and stalagmites in Chamber A (point $\mathrm{C}$ in Fig. 5a). Variation in column thickness along-axis reflects changes in past drip rates; $g$ ) Detail of degrading stalagmite (frame in previous). Weathering and mineral alteration (mineralogy unknown) may be due to reaction of speleothem $\mathrm{CaCO}_{3}$ with by-products of bat guano diagenesis; h) Flowstone, possibly of late Holocene age (?), encrusts detrital floor sediment and landsnail shells (by pencil). Alcove off Chamber A; i) Porous carbonate crust on roof fall block at the SW entrance of the cave (c.f. Fig. 5), deposited by bluegreen algae after ceiling collapse and opening/enlargement of the entrance. This deposit is currently being eroded; j) Stalagmites and columns in alcove off Chamber A. Erosion has exposed speleothem lamination at the base of the column.

Sediment deposition was complex, with various colluvia and, in the upper part of the unit, habitation floor deposits. Reworking of human habitation debris (some of which may have originated further upslope) by surface wash and runnels, bioturbation (see below) and, possibly, human activity, may account for chronological inversions and incongruent radiocarbon dates from the same context (Fig. 8).

\section{Inner cave}

In Chamber B, by contrast, the basal siltstone and carbonate crust - here intensely weathered - are succeeded by about 1.2 to $1.7 \mathrm{~m}$ of unconformable loams and organic/phosphate-rich mud (Unit VI ${ }^{\mathrm{TR} 11,12}$, located under a cupola cluster; Fig. 7). Mud deposition may have taken place in a pool, or on seasonally flooded floor. Above this come poorly sorted loams, locally rich in landsnails and vertebrate bones but devoid of artefacts or other (identifiable) evidence of human presence.

A flowstone crust, locally linking with small, stubby stalagmites, and correlative $\mathrm{CaCO}_{3}$-cemented loams (Unit VIII) can be traced across much of the inner cave floor, on the surface or in shallow subsurface levels (Figs. 7, 9). This late(?) Holocene flowstone signals a renewed phase of calcium carbonate deposition, perhaps as a result of regional climatic change or change in human use of the overcave landscape. A shallow cemented layer interbedded with archaeological deposits near the cave entrance may be correlative with this crust, but this remains to be confirmed. 
Recent deposits (Unit IX: colluvia, winnowed lags, organic mud in the cave well, and various kinds of human-deposited debris in a matrix of floury carbonate(?) dust) reflect the variegated microenvironments of Kuumbi Cave. Human inputs within these are reported to result predominantly from ritual activity.

\section{Postdepositional change}

Sediment diagenesis is spatially variable, evidently reflecting local (cm- to $\mathrm{m}$-scale) hydrological and geochemical conditions across the variegated cave floor. Carbonate cementation is widespread in sediments deposited in inner Chamber B (trenches KC11, KC12) and much less pronounced in the near-entrance talus (trench KC10). Mineral neoformation (with its corollary of possible shell and bone dissolution and potential loss of archaeological evidence) appears to be highly localised. Neomorphs include suspected phosphates/ nitrates(?) in the guano-rich, wet setting of trench KC12 (Fig. 7), and a few calcitic nodules, resulting from recrystallisation of ash deposits, in the entrance talus (trench KC10). Spatially variable diagenesis is common in cave sediments, especially in caves where bat guano deposition is highly localised (cf. Weiner et al., 2002; Shahack-Gross et al., 2004). Higher-resolution (micromorphological and geochemical) analyses are expected to refine this preliminary, field-based picture.

Detrital deposits were affected by bioturbation at various scales, from up to ca. $50 \mathrm{~cm}$ unfilled burrows,

\section{Landforms \& Sediments}

Detrital floor sediments (Unit IX)

Flowstone \& indurated floor (Unit VIII)

Detrital floor sediments (Units V to VII)

Collapse boulders (Unit II)

Cavity formation in floor deposits (Unit IL cemented loams) \& bedrock

Subaqueous speleothems (shelfstone: mammillates) \& wall notche(s) (?)

Indurated loams/breccia (Unit IL)

Subaerial speleothems: parts of Unit II; diachronous Unit SL

Subaqueous speleothems(?): Unit II crust; mammillates (?)
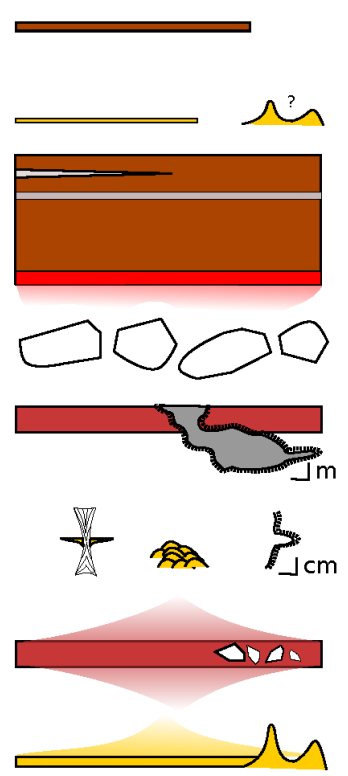

\section{Rod}

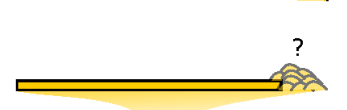

Deposition of $\mathrm{CaCO}_{3}$. Submergence of the cave floor

Red silt \& flowstone (Unit I)

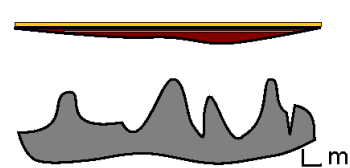

Enlarged cavities, cupolas, bedrock pendants

Eliptical cavities (progressively more inteconnected) during Sea-level highstand(s), or water pooling?

Vadose deposition. Infiltration of fines from overcave surface

Upward-directed phreatic dissolution

probably excavated by small to medium-sized vertebrates (Fig. 7), to numerous tree root channels and terrestrial arthropod galleries (from termites to crabs). Depositional boundaries are, nonetheless, traceable across the exposed profiles and the cave's sediment fill appears to retain its stratigraphic integrity overall.

\section{LATE QUATERNARY SPELEOGENESIS AND LANDSCAPE EVOLUTION}

Cross-cutting and cut-and-fill relationships between erosional landforms, speleothems and detrital sediments permit the establishment of a provisional morphostratigraphy of Kuumbi Cave: a succession of - for the most part undated - phases of wall modification and sediment deposition (Fig. 10). This morphostratigraphy provides the basis for a preliminary reconstruction of cave evolution.

Speleogenetic interpretation of Kuumbi Cave is impeded by a number of lacunae. Our current chronological framework, based on extrapolation from (inferred) marine terrace chronologies and best-fit geological scenarios, is tentative at best. Exploration and survey of karstic landforms, both surface and underground, are limited, and hydraulic and sedimentary links between these landforms are unexplored. Subsurface geology - especially the lithology and hydraulic behaviour of rocks underlying the cavehosting limestone, is also inferred from extrapolation.

\section{Inferred conditions of formation/ deposition}

Colluviation, human activity, bat droppings, degradation of sepeleothems in an open cave (last millennium)

Vadose speleothems \& floor cementation (?)

Intermittent deposition of colluvia and talus (nearentrance); also localised pond(?) deposits in inner cave. Abundant human occupation debris near-entrance. Late Pleistocene (over 20,000 cal. BP)

to Late Holocene (last millennium)

Vadose conditions: localised collapse and opening of the cave

Vadose dissolution: groundwater table was probably Im below cave floor

Deposition of $\mathrm{CaCO}_{3}$ (+ phases of wall dissolution) around water surface. Water pooling and/or elevated water table?

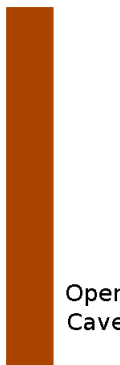

adose deposition of infiltrated fines and roof fall. Roofed cave

Vadose deposition, with ca. $100 \%$ relative humidity. Roofed ca

Vadose 
These limitations notwithstanding, genetic interpretation of Kuumbi Cave (and its wider landscape) is constrained by the following considerations:

- A late Quaternary time frame. As discussed, a tenuous chronology for the formation of the overcave terrace is the later part of the MidPleistocene (tentatively MIS 7: sometime between 240,000 and 190,000 BP).

- Scarcity of surface drainage and stream incision across the Jambiani terraces. This probably suggests that much of the rainwater falling on the surface of this - presumably very porous sediment recharges the carbonate aquifer at the expense of surface runoff. Development of kastic, alongside primary, porosity to take up this recharge must have occurred relatively rapidly, early post-emergence: rapidly enough to prevent the incision of surface drainage.

- Multi-storey, step-like regional karst, that overall 'mirrors' the terraced surface morphology. Each of the two principal terrace levels $(25$ and $<12 \mathrm{~m})$ is underlain by caves.

- Underground karst is not intercepted by surface erosional landforms. None of the (few) visited caves are cut by terrace cliffs or escarpments. Kuumbi and other caves open to the surface via collapse openings and (fewer) solution pipes.

- Abundance of cupolas, cusps and other phreatic dissolution features.

- Well developed speleothems, the bulk of which seems to predate most of the detrital sediment fill.

\section{Flank margin speleogenesis}

The congruence between surface terraces and underterrace cave levels at Jambiani probably reflects an intimate, syngenetic relationship between sea level stands and littoral speleogenesis. Such a link is becoming increasingly recognised in carbonate islands and coastal regions throughout the world. The model of 'flank margin speleogenesis', originally proposed to interpret cave formation in relatively young (Late Cainozoic), eogenetic limestones, and its subsequent evolution into the more generic and nuanced Carbonate Island Karst model emphasise the critical speleogenetic role of the freshwater lens - a feature highly responsive to sea level change (Mylroie \& Carew, 1990; Frank et al., 1998; Mylroie et al., 2001; Fratesi, 2013; Mylroie, 2013). Various processes operating at the seaward (halocline: fresh and seawater mixing zone) and upper (groundwater table) boundaries of this lens promote undersaturation of circulating aqueous solutions in $\mathrm{CaCO}_{3}$, limestone dissolution and the removal of dissolution products. These processes include mixing corrosion (c.f. Bögli, 1980), convection generated by temperature, salinity and (other) density differences and, also, by the pumping effect of tidal flows (potentially a very significant process in Zanzibar's macrotidal coasts), and accumulation of organic debris around groundwater table levels, where percolating meteoric fluids meet slow moving, phreatic water. Accelerated dissolution at the (sea level-controlled) distal margin of the freshwater lens results in formation of flank margin caves of characteristic morphology, at levels associated with former sea level stillstands (Mylroie \& Carew, 1990; Mylroie at al., 2001; Mylroie, 2013 and references therein).

The 'spongework maze' plan of Kuumbi Cave, probably evolved from original porosity that comprised interconnected pores rather than joints (Klimchouk, 2009), is consistent with the overall architecture of flank margin caves in other geologically young carbonate islands (e.g. Guam, the Bahamas, Puerto Rico, Frank et al., 1998; Mylroie et al., 2001). Centimetre-scale elliptical pores distributed at distinct horizontal level(s) in the cave (parallel to, and in part constitutive of the wall 'notch/-es') may exemplify the dimensions and geometry of early karstic porosity, before large chambers had developed.

Cupolas, hemispherical holes and other upwarddirected solution landforms, abundant in Kuumbi Cave, are common in flank margin caves, as much as they are in hypogene caves formed in confined aquifers (Mylroie et al., 1995; Osborne, 2004; Klimchouk, 2009; Mylroie \& Mylroie, 2009; Palmer, 2011). In the envisaged coastal setting of early Kuumbi Cave, tidal pumping may have been a critical driver of aggressive flows some distance from the shore: borehole evidence suggests that tidal brackish groundwater extends for ca. 2-3 km inland from the Jambiani shore, under the $\leq 12 \mathrm{~m}$ terraces (United Nations, 1987; Bron Sikat, 2011).

Figure 11 summarises our proposed reconstruction, based on what evidence is available at present. This reconstruction is in effect a set of hypotheses to be further refined and tested through geochronology, fieldwork and sediment analyses. We interpret Kuumbi and other Jambiani caves as successive generations of flank margin caves, initially formed at around groundwater table level, underneath newly emergent marine terraces. Terrace and cave formation were thus largely concurrent, diachronous processes, driven by the interplay between glacio-eustatic sea level change and crustal uplift of Zanzibar, and extending over several sea level cycles.

\section{Formation of the $25 \mathrm{~m}$ terrace and its underlying caves: later Mid-Pleistocene (MIS 7 to 6)?}

Deposition of the "Older Azania Limestone"

The cave's host rock, bivalve-gastropod packstone/ grainstone of the Older Azania Limestone, was deposited in the warm shallow sea that flooded much of the island during a sea level highstand that predated the Last Interglacial. Its depositional setting was probably that of a relatively low-energy back-reef, similar to the shallow lagoons and platforms that fringe present-day Zanzibar.

As discussed, the age of the Older Azania Limestone is unknown. Notwithstanding this uncertainty, and in analogy with inferences made for other East African Pleistocene limestones at similar altitudes (see above), we propose, as a working hypothesis, the correlation of the Older Azania Limestone with the penultimate interglacial, MIS 7. During the three 'optimal' highstands of MIS 7 (MIS 7e, 7c, 7a; the former lasting for ca. 5,000 years; the latter two for ca. 8,000 years each), eustatic sea level is estimated to have ranged from -15 and to $-5 \mathrm{~m}$ below present (Siddall et al., 
a) Deposition of "Older Azania Limestone" (OAZ)

'Optimal' Mid-Pleistocene highstand(s) (MIS 7: ca. 240-190,000 BP) ? b) Early speleogenesis under emergent terrace 'Suboptimal' MIS 7 highstand(s) ?

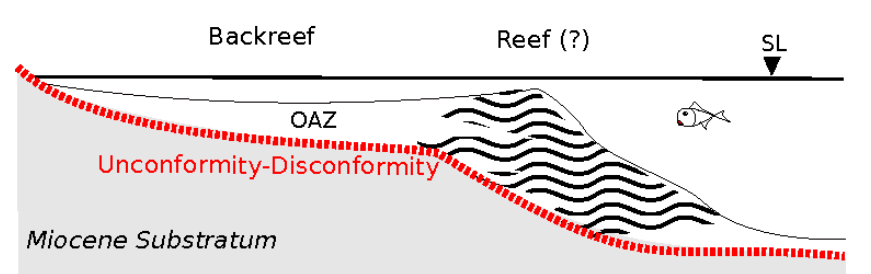

c) Sea level/watertable drop and emergence of cave(s)

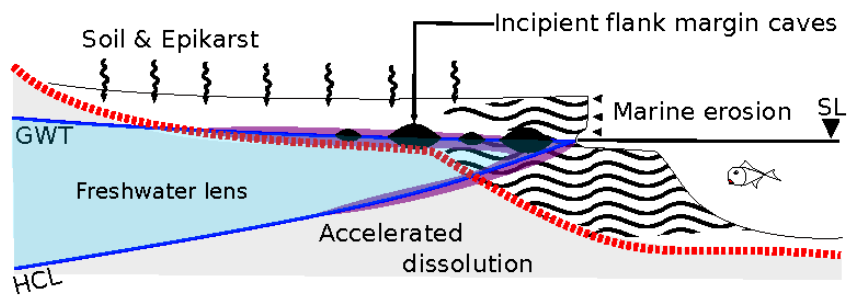

MIS 6 lowstand(s) ?

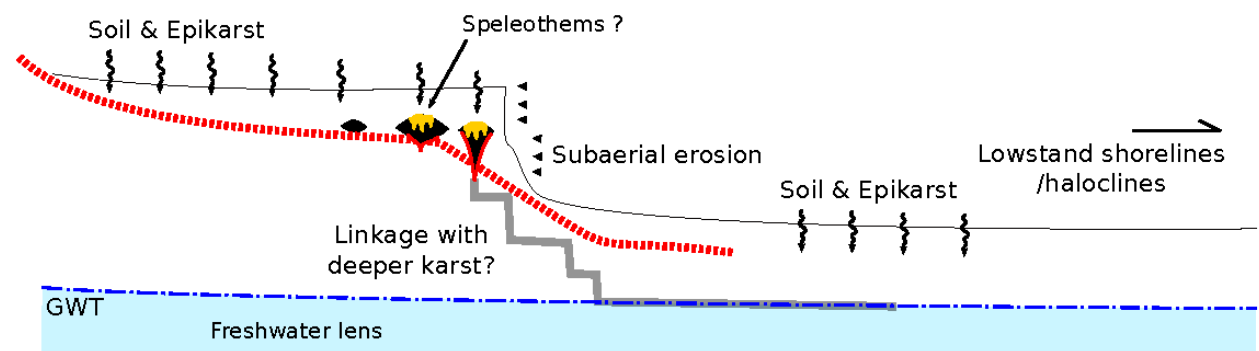

d) Deposition of "Younger Azania Limestone" (YAZ)

'Optimal' MIS 5 highstand(s): 125-75,000 BP?

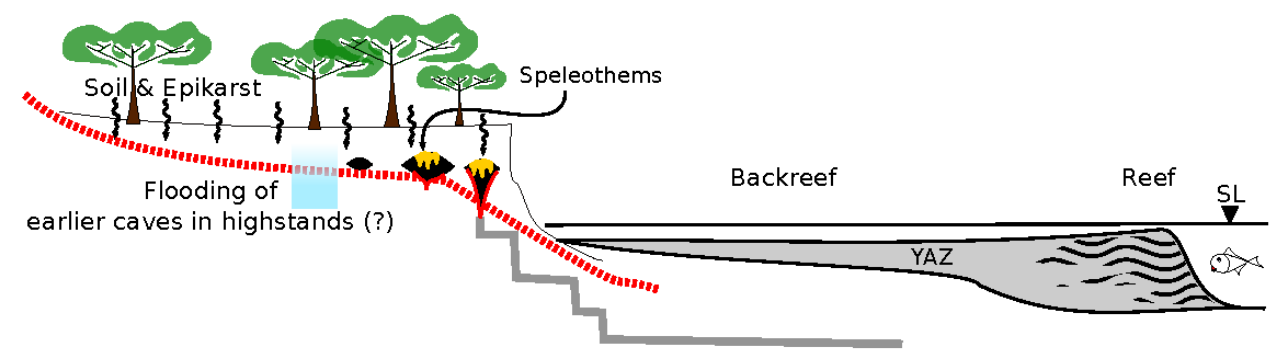

e) Early speleogenesis under emergent terrace(s)

'Suboptimal' MIS 5 highstand(s) ?

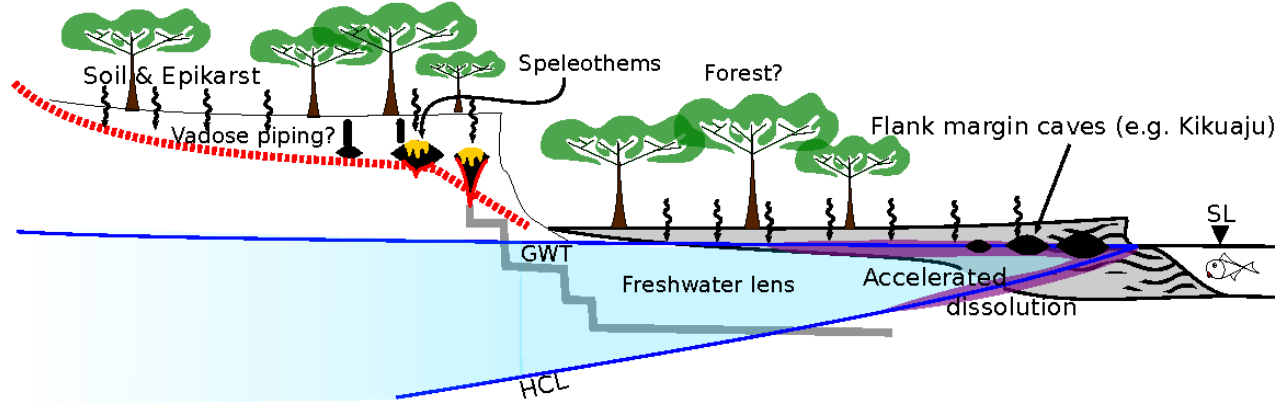

f) Sea level/watertable drop and emergence of caves

Late - terminal Pleistocene (OIS 4 to 2) lowstands ?

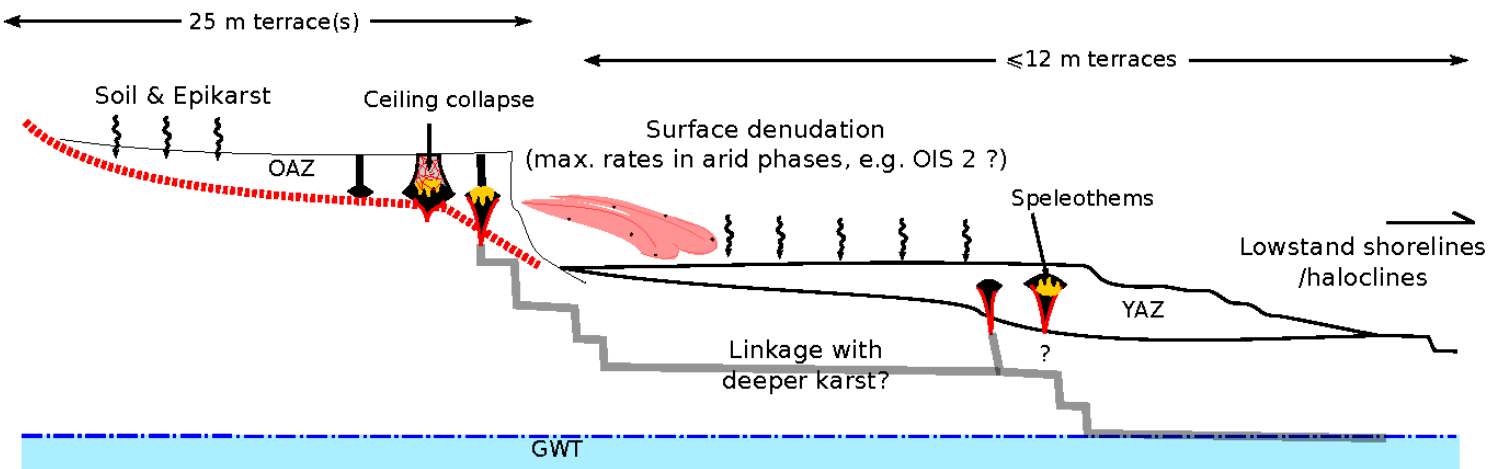

Fig. 11. Inferred late Quaternary evolution of Kuumbi Cave and its wider landscape (see text). 
2006 and references therein). MIS 7 thus afforded about 21,000 years of relatively elevated sea level. Erosion of the terrace platform and deposition of one (or more) carbonate unit(s) took place during one (or more) of these highstands.

\section{Formation of Kuumbi's proto-caverns}

Late Quaternary highstands included long periods during which sea level was high, yet lower than the maximum levels attained during each highstand (Fig. 11b). If the correlation of the Old Azania Limestone with MIS 7 is valid, 'suboptimal' highstand conditions, during which sea level was between -30 and $-20 \mathrm{~m}$ below present, extended for ca. 25,000 years. Moderate drop of eustatic sea level (and, perhaps, the filling of accommodation space by the aggrading/prograding carbonate platform), resulted in repeated(?) emergence and subaerial exposure of parts of the carbonate platform and submersion of the limestone aquifer in a freshwater/brackish water lens. The onset of flank margin speleogenesis, therefore, may have been broadly contemporaneous with (phases of) limestone deposition and terrace formation. Even if the tenuous correlation of the Older Azania Limestone with MIS 7 proves invalid, this reasoning may be applicable to other Pleistocene highstands.

Pulses of crustal uplift may have also induced or accentuated relative sea level drop during highstands. Our current understanding of late Quaternary tectonics of Zanzibar, however, is too sketchy to permit evocation of tectonic factors at these timescales.

During such 'suboptimal' highstands, groundwater that permeated the porous, newly emergent limestone (probably largely uncemented lime sand/ ooze immediately post-emergence) circulated mainly by diffuse, 'Darcynian' flow in an initial network of interparticle and incipient dissolution pores (unlike the fissures and conduits of cemented, telogenetic limestones: c.f. Mylroie \& Carew, 1990; Vacher \& Mylroie, 2002). These pores provided early foci for karstic dissolution: progressively enlarging porosity from which larger cavities were to evolve. Much of this solutional porosity may have emerged fairly rapidly, from preferential dissolution of aragonitic skeletal grains (calcareous green algae plates, whole mollusc shells, scleractinean corals, etc.). Aragonitic grains, unstable in meteoric and mixed water diagenetic environments (Choquette \& Pray, 1970; Longman, 1980), probably abounded in Older Azania Limestone. Mollusc-mouldic pores, like those ubiquitous on the present-day cave walls (Fig. 3d), may thus provide an analogue for incipient karstic porosity.

Incipient flank margin caves, produced by such (largely) even, 'uncompetitive' cavity enlargement, were aligned with the - then - watertable level. The latter is currently poorly constrained, but appears to have stood only a few metres below the $25 \mathrm{~m}$ terrace.

Higher-order fluctuations of the groundwater table during the formative highstand (cf. Esat et al., 1999) may have resulted in repeated draining and flooding of proto-Kuumbi Cave (and other flank margin caves). Notches and subaqueous speleothems in Kuumbi Cave may, therefore, date from these early stages (or from later reflooding or freshwater pooling in the cave: current evidence is too sketchy to permit inferences to be drawn with any confidence).

\section{Draining of the cave}

Eustatic sea level fell dramatically on the wane of the last MIS 7 highstand (MIS 7a). In terminal MIS 7 and MIS 6 (ca. 180,000-135,000 BP), it ranged from -60 to $-120 \mathrm{~m}$ below present (Siddall et al., 2006; Fig. 11c). This (composite) sea level lowstand resulted in prolonged emergence of the Zanzibar shelf, seaward migration of the littoral (perhaps near the shelf-break off the eastern Zanzibar coast), and corresponding drop of the groundwater table.

Groundwater table drop probably drained Kuumbi (and other caves under the $25 \mathrm{~m}$ terrace) for several tens of thousands(?) of years. Water pooling on the cave floor, if present, was probably short-lived, during periods of high rainfall.

Pedogenesis on the overcave terrace, now a low relief surface some distance from the shore, resulted in the development of regolith and soil. Vestiges of cemented regolith on the $25 \mathrm{~m}$ terrace may thus date from this period (or from later Pleistocene times). Fines infiltrated through this inferred soil mantle may have fed some of the earliest(?) detrital deposits in Kuumbi Cave, Unit I red siltstone (Fig. 7). Also, some of the earliest subaerial speleothems in the cave may have formed during this period of prolonged vadose conditions.

Flank margin speleogenesis may have progressed in the seaward parts of the exposed limestone platform during this prolonged sea level lowstand. The form and extent of caves dating to this period is unknown, since such caves, if extant, are now undersea.

Sea level drop must have induced a steep topographic gradient in eastern Zanzibar. The absence of canyons incised through the $25 \mathrm{~m}$ terrace possibly suggests that drainage of (the inner parts of) the exposed shelf was taken up by already well developed underground cavities, but direct evidence for turbulent stream flow (e.g. wall scalloping) is absent. Near-surface cavities may have linked up with even deeper karst though a process of karstic undercutting, but evidence for this is currently lacking, as the lower reaches of the Jambiani karst are inaccessible or unexplored.

\section{Formation of the $\leq 12 \mathrm{~m}$ terrace(s) and caves: Late Pleistocene (MIS 5)?}

\section{'Younger Azania Limestone' and terraces}

Eustatic sea level rose again and the warm shallow sea transgressed the eastern Zanzibar shelf. The shallow-marine carbonates of the 'Younger Azania Limestone' (coral bioherms and coral-algal rudstones on and around reefs, grainstones in beaches and backreef shoals), were deposited as a result. In the stratigraphic scheme proposed here, Younger Azania Limestone deposition is attributed to one (or more?) highstand(s) of the composite MIS 5 (ca. 130-70,000 $\mathrm{BP})$ - perhaps around MIS 5e (ca. 128-115,000 BP), when sea level was between 0 and $+6 \mathrm{~m}$ (Siddal et al., 2006). Several closely spaced, mainly(?) erosive marine terraces from $+12 \mathrm{~m}$ to present sea level may have resulted from coastal erosion during shorter- 
lived, intra-MIS 5 highstands (Lambeck \& Chappell, 2001; Siddall et al., 2006; Fig. 2).

\section{Formation of Kikuaju and neighbouring caves}

Large parts of the Last Interglacial carbonate shelf became emergent repeatedly during suboptimal intraMIS 5 highstands. Recapitulation of the diagenetic and cave-forming processes that had previously affected the 'Older Azania Limestone' resulted in a younger generation of - apparently smaller - flank margin caves under the $\leq 12 \mathrm{~m}$ terraces. Kikuaju A and $B$ (and, perhaps, other caves under the Jambiani coastal plain) probably formed in this period (Fig. 11e).

\section{Last Interglacial speleothems?}

Kuumbi Cave probably remained emergent, or only partly submerged (in optimal highstands, and/or due to water pooling during most of the Last Interglacial. Regional climate was probably warm and moist, with at least ca. 10,000 years of monsoon (Yuan et al., 2004; Chiang, 2009). We hypothesise that much of the speleothem deposition in Kuumbi Cave (Units St, II) dates from the Last Interglacial. High rainfall and prolific vegetation growth and pedogenesis on the overcave terrace may have enhanced limestone dissolution in the epikarst and deposition of vadose speleothems in the cave. Possible subaqueous speleothems (mammillates, shelfstones) may also date from Last Integlacial flooding of the cave floor, but their relative dating is uncertain.

\section{Vadose to open cave: Late Pleistocene (MIS 4 to 2)}

Drained caves and terminal Pleistocene speleothems

Base level fell on the wane of the Last Interglacial, from $-60 \mathrm{~m}$ in MIS 3 times to $-120 \mathrm{~m}$ in the LGM (Siddall et al., 2006). This prolonged Late Pleistocene lowstand resulted in groundwater table drop and emergence of under-terrace caves, as coastal speleogenetic environments migrated seawards (perhaps to the shelf break/shelf slope east of the Jambiani coast). It is possible that underground karst formed during this prolonged but multi-phase lowstand, but its configuration and hydraulic connectedness with highstand caves, such as Kuumbi and Kikuaju, are unknown. Flank margin caves resulting from lowerthan-present sea level highstands during MIS 3 $(-50$ to $-60 \mathrm{~m})$ may lie submerged offshore; however, their presence and distribution are unconfirmed.

Subaerial speleothems were probably deposited in both Kuumbi and Kikuaju caves in this later part of the Pleistocene. Much of the speleothem deposition may have occurred during warm and moist phases (e.g. MIS 3), and, also, in terminal Pleistocenebeginning of the Holocene, before rising sea level partially submerged caves under the $\leq 12 \mathrm{~m}$ terrace(s) (e.g. Kikuaju cave 'springs') in brackish water.

\section{Opening of Kuumbi Cave}

Drained of groundwater that had provided hydrostatic support, and undermined by earlier dissolution, Kuumbi Cave was structurally unstable and prone to collapse (cf. Gillieson, 1996; Osborne, 2002). Collapse events may have occurred several times in the history of Kuumbi and other caves in the region (as manifest by the numerous collapse dolines that dot the Jambiani terraces).

The earliest documented collapse event in Kuumbi Cave (manifest by the Unit IIIT10 collapse boulders) probably dates to the Late Pleistocene, before ca. 25,000 cal. BP (the earliest radiocarbon dates, from landsnail in interboulder colluvial fill space: c.f. Sinclair et al., 2006). This event transformed a substantial part the cave into a collapse doline.

Collapse blocks remained exposed to the elements for a long period before their burial by red colluvium (Unit IV ${ }^{\mathrm{TR} 10}$ ), as episodic sheetwash, debris flows and small runnels scoured the slope and overcave surface. Much of this colluvium appears to have been derived from erosion of a red soil. Soil erosion may have been enhanced by low/sparse vegetation - perhaps shrubland or open woodland. These entrance colluvia possibly reflect arid climatic conditions, consistent with those prevailing over much of equatorial East Africa during MIS 2, when monsoonal circulation was severely weakened (Yuan et al., 2004; Kiage \& Liu, 2006; Barker, 2007; Chiang, 2009).

Opening of the cave amounted to a radical refashioning of its physical environment (temperature, $\mathrm{P}_{\mathrm{CO} 2}$, air circulation, humidity) and ecology. These changes must have impacted on carbonate equilibria dynamics in recharging solutions, and thus on the rate of speleothem deposition. Air circulation through the enlarged entrance(s) also caused localised erosion of speleothems at this and later times. From this point onwards, Kuumbi Cave has been accessible to large plants (e.g. tree roots) and animals, including humans. Significantly, the earliest shells of Achatina landsnails occur in interstices between Unit III TR10 collapse boulders.

\section{Kuumbi's first humans}

It is in this entrance talus that the earliest definitive evidence for human presence in and around Kuumbi Cave was discovered by earlier researchers (Sinclair et al., 2006; Chami, 2008) and confirmed by our excavations: a dense accumulation of Achatina landsnails comingled with marine molluscs, mammalian remains, charcoal and lithics, dated to ca. 18,500-17,000 cal. BP. Scarce charcoal and marine molluscs in underlying sediments raise the possibility of even earlier sporadic human presence. The terminal Pleistocene foragers who inhabited Kuumbi Cave preyed upon a diverse array of mammals, including zebra, buffalo and several other taxa currently extinct in Zanzibar.

\section{Abandonment, re-occupation and landscape change: Holocene (MIS 1)}

Colluvial deposition continued on the entrance talus and elsewhere in the cave in Holocene times. A paucity of radiocarbon dates between the terminal Pleistocene and late Holocene may indicate that the cave (and its surroundings?) became depopulated in early Holocene times. Holocene sea level rise resulted in rapid transformation of Zanzibar into an island ca. 11,000-10,000 cal. BP (Ruby, pers. comm. 2015). Links between the rapidly changing island landscape 
and the demographic and ecological responses of Zanzibar's human and (other) mammalian inhabitants are being investigated through ongoing faunal analyses, palaeogeographical modelling and environmental reconstruction.

Later Holocene near-entrance sediments at Kuumbi Cave largely consist of human-deposited debris with terrestrial and marine animal remains, LSA lithics and, in the upper parts, Iron Age pottery (Unit VII ${ }^{\mathrm{TR} 10}$ ), indicating intensification of human habitation in and around the cave. Cave users practiced a broad spectrum foraging economy that showed considerable continuity over time (Shipton et al., in press). Ubiquitous marine shell and small amounts of fish bone demonstrate that Kuumbi Cave was part of an inhabited landscape that extended to the ocean shore and the shallow shelf beyond.

The presence of a shallow, presumably Holocene, carbonate crust and correlative $\mathrm{CaCO}_{3}$-cemented floor deposits in the inner cave floor manifests a shift in cave depositional dynamics: accelerated rates of carbonate deposition may reflect changes in the hydrologic regime and/or sediment dynamics in the cave catchment, the $25 \mathrm{~m}$ terrace. These changes may have been driven by Holocene climate change, changing human practices of land use, or the combined effects of both.

Ongoing reorganisation of the cave's environment, triggered by further, localised ceiling collapse, probably resulted in an overall drier cave atmosphere, and, also, in insolation of a large part of the cave. Photosynthetic algal communities (that cover much the present cave walls) may have been a major agent of bioerosion, contributing copious quantities of fine carbonate matrix (cf. Northup \& Lavole, 2001).

\section{The last few centuries}

Human presence in Kuumbi Cave appears to have been sporadic in these later times, as indicated by the lower frequency of material culture and other human-induced deposits in late Holocene Unit IX. Oral tradition, as recorded by Chami (2008), hints at a lull in human use and, even, knowledge of Kuumbi Cave: reportedly, the cave was rediscovered by a couple searching for a place 'to consummate their relationship'. This tradition also records the presence of a water pool in the rear part of the cave, presumably caused by a somewhat elevated watertable.

Human visitation in the very recent past may have been mainly for drawing water from the cave well, conducting spirit worship rituals (c.f. Chami, 2008), and, in the last decade, tourism.

\section{CONCLUSIONS}

Kuumbi Cave, on the eastern Zanzibar littoral, is one of several caves under a flight of Pleistocene marine terraces. Terraces and caves formed in two porous limestone units, an older one, tenuously correlated with the Penultimate Interglacial highstand (MIS 7) - but which could also be much older, and a younger one, correlated with the Last Interglacial (MIS 5). Speleogenesis and terrace formation are interpreted as broadly contemporaneous (i.e. within the same Milankovitch-scale glacioeustatic cycle), shaped by the interplay between glacioeustatic sea level change, karstic dissolution around highstand groundwater tables, and ceiling collapse, in a coast undergoing crustal uplift, perhaps at the order of ca. 0.10-0.20 mm/yr.

Kuumbi Cave formed as a flank margin cave during 'suboptimal' highstands, by dissolution around the seaward parts of the freshwater lens when sea level/groundwater table was a few metres under the emergent carbonate shelf (25 $\mathrm{m}$ terrace). Phreatic to epiphreatic speleogenesis in these early phases resulted in the formation of a spongework maze, with cusps and upward-directed solution cavities (cupolas). Early-stage speleogenesis progressed fast enough for nascent underground porosity to take up much of the drainage of the overcave terrace. Rapid dissolution may have been favoured by high primary porosity and the unstable, aragonitic composition of skeletal grains in the limestone aquifer. A proposed period of early speleogenesis is the Penultimate Interglacial (MIS 7).

Lowering of the groundwater table in sea level lowstands (intra-MIS 7 lowstands?; MIS 6?) resulted in repeated draining of Kuumbi Cave. The earliest detrital sediments and carbonate speleothems may date from these times (especially from MIS 6), but geochronological confirmation is wanting. Possible subaqueous speleothems record episodes of cave floor flooding, perhaps triggered by high-order sea level cyclicity and/or water pooling.

Marine transgression of the Zanzibar littoral in the Last Interglacial resulted in limestone deposition (probably in MIS 5e) and terrace formation ( $\leq 12 \mathrm{~m}$ terraces). Flank margin caves formed under these terraces during suboptimal, intra-MIS 5 highstands. These caves were drained and transformed to vadose chambers in the course of Late Pleistocene (MIS 4 to 2) sea level/groundwater table fall. High rainfall, lush vegetation and well developed soils in the warm and humid Last Interglacial may have promoted deposition of vadose speleothems in caves under the higher, $25 \mathrm{~m}$ terrace. We hypothesise that many of Kuumbi Cave's speleothems date from this period.

Late Pleistocene (but pre-ca. 22,000 cal. BP) collapse of part of the Kuumbi Cave ceiling, already undermined by earlier phreatic dissolution, amounted to major reorganisation of the cave environment. From this point onwards, Kuumbi Cave received large quantities of detrital sediment from the overcave surface and was accessible to large surface biota.

Near-entrance sediments record the evolution of an entrance talus from this terminal Pleistocene collapse to the present. Colluvia burying collapse boulders resulted from erosion of a seemingly drier, more sparsely vegetated terminal Pleistocene (ca. 22,000 cal. BP) landscape. Later talus sediments include terminal Pleistocene (18,500-17,000 cal. BP) deposits of Achatina spp. landsnails and other fauna, associated with human occupation and, after a prolonged habitation hiatus, later Holocene colluvia and floor deposits with diverse human inputs: terrestrial snails and marine mollsucs, vertebrate bones, ash 
and charcoal, lithics, and, in shallower strata, Iron Age ceramics. Erosional surfaces and palaeofloors suggest that sediment deposition was discontinuous, with pulses of sediment flux, separated by periods of little deposition and/or erosion.

Inner cave deposits include the filling of floor depressions by silt and bat guano and later floor wash deposits with no apparent human inputs.

A shallow flowstone crust and correlative $\mathrm{CaCO}_{3}-$ cemented floor, may record a late(?) Holocene shift in cave depositional dynamics. This may have been caused by regional climate change (increase in rainfall rates), and/or human-mediated vegetation change on the overcave terrace.

In recent times Kuumbi Cave has been a ritual space, seasonal water resource, marker of Swahili heritage and identity, and a tourist destination of growing importance. The cave and its wider landscape are highly significant - and contested - places for members of the Jambiani community. Future research on these landforms should engage actively with their local users and custodians.

\section{ACKNOWLEDGEMENTS}

The Sealinks Project is funded by a European Research Council (ERC) grant to N. Boivin (Starter Grant 206148, 'SEALINKS), under the 'Ideas' specific Programme of the 7th Framework Programme (FP7). Ceri Shipton and Alison Crowther were funded by postdoctoral fellowships from the University of Queensland and the British Academy, respectively. Llorenç Picornell was funded by a postdoctoral fellowship by the Conselleria d'Educació, Cultura i Universitats (Government of the Balearic Islands) and the European Social Fund. Fieldwork at Kuumbi Cave was carried out under a research permit issued by the Office of Chief Government Statistician, Zanzibar Research Committee, and an excavation license issued by the Zanzibar Department of Museums and Antiquities. We gratefully acknowledge the support of the Zanzibar Department of Antiquities, particularly Amina Issa and Abdallah Khamis. The work was also undertaken with the permission and collaboration of the cave's local custodians, particularly: Bandari Ame Haji, Asha Ali Makame, Meja Haji Nyonje, Nyonje Pandu Nyonje and Hassan Ali. We are indebted to Joaquin Ginés, Bogdan P. Onac and two anonymous reviewers for their thorough and constructive reviews that greatly improved earlier drafts of this paper.

\section{REFERENCES}

Abuodha J.O.Z., 2004 - Geomorphological evolution of the southern coastal zone of Kenya. Journal of African Earth Sciences, 39: 517-525.

http://dx.doi.org/10.1016/j.jafrearsci.2004.07.012

Arthurton R., 2003 - The fringing reef coasts of Eastern Africa - Present processes in their long-term context. Western Indian Ocean Journal of Marine Science, 2: 1-13.

Arthurton R.S., Brampton A.H., Kaaya C.Z. \& Mohamed S.K., 1999 - Late Quaternary coastal stratigraphy on a platform-fringed tropical coast: a case study from Zanzibar, Tanzania. Journal of Coastal Research, 15: 635-644.
Barker P.A., 2007 - The Monsoon's past. Science, 316: 1295-1296.

http://dx.doi.org/10.1126/science. 1143451

Battistini R., 1977 - Ages absolus Th230/Ur234 de depots marins Pleistocenes à Madagascar et dans les fles voisines. Madagascar Revue de Geographie, 31: 73-86.

Birmingham A.B., Mylroie J.R., Mylroie J.E. \& Lace M.J., 2011 - Bell hole origin: constraints on developmental mechanisms, Crooked Island, Bahamas. Speleogenesis and Evolution of Karst Aquifers, 10: 70-79.

Bögli A., 1980 - Karst hydrology and physical speleology. Springer, Berlin, 284 p.

http://dx.doi.org/10.1007/978-3-642-67669-7

Boivin N., Fuller D.Q. \& Crowther A., 2012 - Old world globalization and the Columbian exchange: Comparison and contrast. World Archaeology, 44: 452-469. http://dx.doi.org/10.1080/00438243.2012.729404

Boivin N., Crowther A., Helm R. \& Fuller D., 2013 - East Africa and Madagascar in the Indian Ocean World. Journal of World Prehistory, 26: 213-281. http://dx.doi.org/10.1007/s10963-013-9067-4

Boivin N., Crowther A., Prendergast M. \& Fuller D.Q., 2014 - Indian Ocean food globalisation and Africa. African Archaeological Review, 31: 547-581. http://dx.doi.org/10.1007/s10437-014-9173-4

Bover P., Valenzuela A., Guerra C., Rofes J., Alcover J.A., Ginés J., Fornés J.J., Cuenca-Bescós G. \& Merino A., 2014 - The Cova des Pas de Vallgornera (Llucmajor, Mallorca): a singular deposit bearing an exceptional well preserved Early Pleistocene vertebrate fauna. International Journal of Speleology, 43: 175-192. http://dx.doi.org/10.5038/1827-806X.43.2.6

Braithwaite C.J.R., 1984 - Depositional history of the late Pleistocene limestones of the Kenya coast. Journal of the Geological Society, 141: 685-699. http://dx.doi.org/10.1144/gsjgs.141.4.0685

Bron Sikat L., 2011 - Assessing the spatial and temporal characteristics of groundwater recharge in Zanzibar: towards the optimal management of groundwater resources. Unpublished MSc thesis, University of Twente, $43 \mathrm{p}$.

Caswell P.V., 1956 - Geology of the Kilifi-Mazeras area. Geological Survey of Kenya, Nairobi, 54 p.

Chami F.A., 2008 - Diffusion in the studies of the African past: reflections from new archaeological findings. African Archaeological Review, 24: 1-14. http:/ /dx.doi.org/10.1007/s10437-007-9012-y

Chami F.A., 2009 - Excavation of Kuumbi Cave, Zanzibar. In: Chami F.A. (Ed.), Zanzibar and the Swahili Coast from c. 30,000 years ago. E\&D Vision Publishing, Dar es Salaam, p. 41-78.

Chiang J.C.H., 2009 - The tropics in paleoclimate. Annual Reviews in Earth and Planetary Sciences, 37: 263-297. http://dx.doi.org/10.1146/annurev.earth.031208.100217

Choquette P.W. \& Pray L.C., 1970 - Geologic nomenclature and classification of porosity in sedimentary carbonates. American Association of Petroleum Geologists Bulletin, 54: 207-250.

Chorowicz J., 2005 - The East African rift system. Journal of African Earth Sciences, 43: 379-410.

http://dx.doi.org/10.1016/j.jafrearsci.2005.07.019

Crowther A., Horton M., Kotarba-Morley A., Prendergast M., Quintana Morales E., Wood M., Shipton C., Fuller D.Q., Tibesasa R., Mills W. \& Boivin N., 2014a - Iron Age agriculture, fishing and trade in the Mafia archipelago, Tanzania: new evidence from Ukunju Cave. Azania, 49: 21-44.

http://dx.doi.org/10.1080/0067270X.2013.878104 
Crowther A., Veall M-A., Boivin N., Horton M., KotarbaMorley A., Fuller D.Q., Fenn T., Haji O. \& Matheson C.D., 2014b. - Use of Zanzibar copal (Hymenaea verrucosa Gaertn.) as incense at Unguja Ukuu, Tanzania in the 7-8 $8^{\text {th }}$ century CE: chemical insights into trade and Indian Ocean interactions. Journal of Archaeological Science, 53: 374-390.

http://dx.doi.org/10.1016/j.jas.2014.10.008

De Waele J., 2009 - Evaluating human disturbance on Mediterranean karst areas: the example of Sardinia, Italy. Environmental Geology, 58: 239-255. http://dx.doi.org/10.1007/s00254-008-1600-x

Esat T.M., McCulloch M.T., Chappell J., Pillans B. \& Omura A., 1999 - Rapid fluctuations in sea level recorded at Huon Peninsula during the penultimate deglaciation. Science, 283: 197-201.

http://dx.doi.org/10.1126/science.283.5399.197

Farrant A.R. \& Smart P.L., 2011 - Role of sediment in speleogenesis; sedimentation and paragenesis. Geomorphology, 134: 79-93.

http://dx.doi.org/10.1016/j.geomorph.2011.06.006

Fornós J.J., Ginés J., Gràcia F., Merino A., Juncadella A.M., Gómez-Pujol L. \& Bover P., 2014 - Cave deposits and sedimentary processes in Cova des Pas de Vallgornera (Mallorca, Western Mediterranean). International Journal of Speleology, 43: 159-174. http://dx.doi.org/10.5038/1827-806X.43.2.5

Frank E.F., Mylroie J., Troester J., Calvin Alexander Jr. E. \& Carew J.L., 1998 - Karst development and speleogenesis, Isla de Mona, Puerto Rico. Journal of Cave and Karst Studies, 60: 73-83.

Fratesi B., 2013 - Hydrology and geochemistry of the freshwater lens in coastal karst. In: Lace M.J. \& Mylroie J.E. (Eds.), Coastal karst landforms. Springer, Berlin, p. $59-75$.

http://dx.doi.org/10.1007/978-94-007-5016-6_3

Fuller D.Q. \& Boivin N., 2009 - Crops, cattle and commensals across the Indian Ocean: current and potential archaeobiological evidence. Études Ocean Indien, 42/43: 13-46.

Fuller D.Q., Boivin N., Castillo C., Hoogervorst T. \& Allaby R.G., 2014 - The archaeobiology of Indian Ocean translocations: current outlines of cultural exchanges by proto-historic seafarers. In: Tripati S. (Ed.), Maritime contacts of the past: deciphering connections amongst communities. Delta Book World, New Delhi, p. 1-23.

Fuller D.Q., Boivin N. \& Hoogervorst T., 2011 - Across the Indian Ocean: the prehistoric movement of plants and animals. Antiquity, 85: 544-558. http://dx.doi.org/10.1017/S0003598X00067934

Gillieson D., 1996 - Caves: processes, development, management. Blackwell, Oxford, 324 p. http://dx.doi.org/10.1002/9781444313680

Ginés A. \& Ginés J., 2007 - Eogenetic karst, glacioeustatic cave pools and anchialine environments on Mallorca Island: a discussion of coastal speleogenesis. International Journal of Speleology, 39: 57-67. http://dx.doi.org/10.5038/1827-806X.36.2.1

Ginés J., Fornós J.J., Ginés A., Merino A. \& Gràcia F., 2014 - Geologic constraints and speleogenesis of Cova des Pas de Vallgornera, a complex coastal cave from Mallorca Island (Western Mediterranean). International Journal of Speleology, 43: 105-124. http://dx.doi.org/10.5038/1827-806X.43.2.2

Harris E.C., 1989 - Principles of archaeological stratigraphy. Academic Press, London, $169 \mathrm{p}$.

Helm R., Crowther A., Shipton C., Tengeza A., Fuller D.Q. \& Boivin N., 2012 - Exploring agriculture, interaction and trade on the eastern African littoral: preliminary results from Kenya. Azania, 47: 39-63.

http://dx.doi.org/10.1080/0067270X.2011.647947
Jennings J.M., 1985 - Karst geomorphology. Blackwell, Oxford, 293 p.

Kent P., Hunt J. \& Johnstone D., 1971 - The geology and geophysics of coastal Tanzania. Institute of Geological Sciences, London, Special Paper, 101 p.

Kiage L.M. \& Liu K., 2006 - Late Quaternary paleoenvironmental changes in East Africa: a review of multiproxy evidence from palynology, lake sediments, and associated records. Progress in Physical Geography, 30: 633-658.

http://dx.doi.org/10.1177/0309133306071146

Klimchouk A., 2009 - Morphogenesis of hypogenic caves. Geomorphology, 106: 100-117.

http://dx.doi.org/10.1016/j.geomorph.2008.09.013

Lace M.J. \& Mylroie J.E., 2013 - The biological and archaeological significance of coastal cave and karts features. In: Lace M.J. \& Mylroie J.E. (Eds.), Coastal karst landforms. Springer, Berlin, p. 111-126. http://dx.doi.org/10.1007/978-94-007-5016-6 5

Lambeck K. \& Chappell J., 2001 - Sea level change through the last glacial cycle. Science, 292: 679-686. http://dx.doi.org/10.1126/science.1059549

Lismonde B., 2000 - Corrosion des coupoles de plafond par les fluctuations de pression de l'air emprisonné. Karstologia, 35: 39-46.

Longman M.W., 1980 - Carbonate diagenetic textures from nearsurface diagenetic environments. American Association of Petroleum Geologists Bulletin, 64: 461-487.

Lundberg J. \& McFarlane D.A., 2009 - Bats and bell holes: the microclimatic impact of bat roosting, using a case study from Runaway Bay Caves, Jamaica. Geomorphology, 106: 78-85.

http://dx.doi.org/10.1016/j.geomorph.2008.09.022

Miklavic B., Mylroie J.E., Jenson J.W., Randall R.H., Banner J.L. \& Partin J.W., 2012 - Interglacial limestone and its geomorphic features on Guam: implications for relative sea-level change and flank margin cave formation. In: Gamble D.W. \& Kindler P. (Eds.), Proceedings of the $15^{\text {th }}$ Symposium on the Geology of the Bahamas and other Carbonate Regions. Gerace Research Center, San Salvador, Bahamas, p. 107-115.

Mpanda S., 1997 - Geological development of the East African coastal basin of Tanzania. Almqvist \& Wiksell International, Stockholm, $121 \mathrm{p}$.

Mylroie J.E., 2013 - Coastal karst development in carbonate rocks. In: Lace M.J. \& Mylroie J.E. (Eds.), Coastal karst landforms. Springer, Berlin, p. 77-109. http://dx.doi.org/10.1007/978-94-007-5016-6_4

Mylroie J.E. \& Carew J.L., 1990 - The flank margin model for dissolution cave development in carbonate platforms. Earth Surface Processes and Landforms, 15: 413-424. http://dx.doi.org/10.1002/esp.3290150505

Mylroie J.E., Carew J.L. \& Vacher H.L., 1995 - Karst development in the Bahamas and Bermuda. In: Curran H.A. \& White B. (Eds.), Terrestrial and shallow marine geology of the Bahamas and Bermuda. Geological Society of America, Boulder, CO, Special Paper, p. 251-267.

http://dx.doi.org/10.1130/0-8137-2300-0.251

Mylroie J.E., Jenson J.W., Taboroshi D., Jocson J.M.U., Vann D.T. \& Wexel C., 2001 - Karst features of Guam in terms of a general model for carbonate island karst. Journal of Cave and Karst Studies, 63: 9-22.

Mylroie J.E. \& Mylroie J.R., 2007 - Development of the Carbonate Island Karst Model. Journal of Cave and Karst Studies, 69: 59-75. 
Mylroie J.E. \& Mylroie J.R., 2009 - Diagnostic features of hypogenic karst: is confined flow nececessary? In: Stafford K.W., Land L. \& Veni G. (Eds.), Advances in hypogene karst studies. National Cave and Karst Research Institute Symposium 1, National Cave and Karst Research Institute, Carlsbad, NM, p. 12-26.

Mylroie J.E., Mylroie J.R. \& Nelson C.S., 2008 - Flank margin cave development in telogenetic limestones of New Zealand. Acta Carsologica, 37: 15-40.

Mylroie J.E. \& Vacher H.L., 1999. - A conceptual view of carbonate island karst. In: Palmer A.N., Palmer M.V. \& Sasowsky I.D. (Eds.), Karst modeling, Karst Waters Institute, Charles Town, WV, Special Publication, 48-57.

Nicholas C.J., Pearson P.N., McMillan I.K., Ditchfield P.W. \& Singano J.M., 2007 - Structural evolution of southern coastal Tanzania since the Jurassic. Journal of African Earth Sciences, 48: 273-297.

http://dx.doi.org/10.1016/j.jafrearsci.2007.04.003

Nortup D.E. \& Lavole K.H., 2001 - Geomicrobiology of caves: a review. Geomicrobiology Journal, 18: 199-222. http://dx.doi.org/10.1080/01490450152467750

Oosterom A.P., 1988 - The geomorphology of southern Kenya. Unpublished Doctoral thesis, Agricultural University, Wagenigen, $227 \mathrm{p}$.

Osborne R.A.L., 2002 - Cave breakdown by vadose weathering. International Journal of Speleology, 31: 37-53. http://dx.doi.org/10.5038/1827-806X.31.1.3

Osborne R.A.L., 2004 - The trouble with cupolas. Acta Carsologica, 33/2: 9-36.

Palmer A.N., 2011 - Distinction between epigenic and hypogenic maze caves. Geomorphology, 134: 9-22. http://dx.doi.org/10.1016/j.geomorph.2011.03.014

Piccini L., Forti P., Giulivo I. \& Meccia M., 2007 - The polygenetic caves of Cuatro Ciénegas (Coachuila, Mexico): morphology and speleogenesis. International Journal of Speleology, 36: 83-92.

http://dx.doi.org/10.5038/1827-806X.36.2.4

Punwong P., Marchant R. \& Selby K., 2013a - Holocene mangrove dynamics in Makoba Bay, Zanzibar. Palaeogeography, Palaeoclimatology, Palaeoecology, 379/380: 54-67.

http://dx.doi.org/10.1016/j.palaeo.2013.04.004

Punwong P., Marchant R. \& Selby K., 2013b - Holocene mangrove dynamics from Unguja Ukuu, Zanzibar. Quaternary International, 298: 4-19.

http://dx.doi.org/10.1016/j.quaint.2013.02.007

Reuter M., Piller W.E., Harzhauser M., Berning B. \& Kroh A., 2010 - Sedimentary evolution of a late Pleistocene wetland indicating extreme coastal uplift in southern Tanzania. Quaternary Research, 73: 136-142. http://dx.doi.org/10.1016/j.yqres.2009.09.004

United Nations, 1987 - Hydrogeological map of Zanzibar, including the islands of Zanzibar and Pemba, The United Republic of Tanzania, Scale 1:125,000, United Nations, New York.

Sancho C., Peña J.L., Mikkan R., Osácar C. \& Quinif Y., 2004 - Morphological and speleothemic development in Brujas Cave (Southern Andean Range, Argentine): palaeoenvironmental significance. Geomorphology, 57: 367-384.

http://dx.doi.org/10.1016/S0169-555X(03)00166-1

Sasowsky I.D. \& Mylroie J.E. (Eds.), 2004 - Studies of cave sediments: physical and chemical records of paleoclimate. Springer, Dordrecht, 329 p. http://dx.doi.org/10.1007/978-1-4419-9118-8
Shahack-Gross R., Berna F., Karkanas P. \& Weiner S., 2004 - Bat guano and preservation of archaeological remains in cave sites. Journal of Archaeological Science, 31: 1259-1272.

http://dx.doi.org/10.1016/j.jas.2004.02.004

Shipton C., Crowther A., Prendergast M.E., Kourampas N., Horton M., Douka K., Schwenninger J-L., Faulkner P., Quintana-Morales E.M., Langley M., Tibesasa R., Picornell-Gelabert L., Doherty C., Wilmsen E., Petraglia M. \& Boivin N., (in press, 2015) - Reinvestigation of Kuumbi Cave, Zanzibar, reveals stratigraphic complexity and discontinuous human occupation spanning the Late Pleistocene to Late Holocene. Azania.

Shipton C., Helm R., Boivin N., Crowther A., Austin P. \& Fuller D., 2013 - Intersections, networks and the genesis of social complexity on the East African coast. African Archaeological Review, 30: 427-453.

http://dx.doi.org/10.1007/s10437-013-9140-5

Siddall M., Chappell J. \& Potter E-K., 2006 - Eustatic sea levels during past interglacials. In: Sirocko F., Claussen M., Litt T. \& Sanchez-Goni M.F. (Eds.), The climate of past interglacials. Elsevier, Amsterdam, p. 75 - 92.

Sinclair P., Juma A. \& Chami F., 2006 - Excavations in Kuumbi Cave in Zanzibar in 2005. Studies in the African Past, 5: 95-106.

Stockley G.M., 1928 - Report on the geology of the Zanzibar Protectorate. Government of Zanzibar, Zanzibar, 126 p.

Sweeting M.M., 1972 - Karst landforms. Macmillan, London, 362 p.

Trudgill S.T., 1985 - Limestone geomorphology. Longman, London, $196 \mathrm{p}$.

Tuccimei P., Soligo M., Ginés J., Ginés A., Fornós J.J., Kramers J. \& Villa I.M., 2010 - Constraining Holocene sea levels using U-Th ages of phreatic overgrowths on speleothems from coastal caves in Mallorca (Western Mediterranean). Earth Surface Processes and Landforms, 35: 782-790. http://dx.doi.org/10.1002/esp.1955

Vacher H.L. \& Mylroie J.E., 2002 - Eogenetic karst from the perspective of an equivalent porous medium. Carbonates and Evaporites, 17: 182-196. http://dx.doi.org/10.1007/BF03176484

Van Beynen P., Bourbonniere R., Ford D.C. \& Schwarcz H., 2001 - Causes of colour and fluorescence in speleothems. Chemical Geology, 175: 319-341. http://dx.doi.org/10.1016/S0009-2541(00)00343-0

Veldkamp A, Buisa E., Wijbrans J.R., Olagoc D.O., Boshovena E.H., Marée M. \& van den Berg van Saparoea R.M., 2007 - Late Cenozoic fluvial dynamics of the River Tana, Kenya, an uplift dominated record. Quaternary Science Reviews, 26: 2897-2912. http://dx.doi.org/10.1016/j.quascirev.2007.06.033

Weiner S., Goldberg P. \& Bar-Yosef O., 2002 - Threedimensional distribution of minerals in the sediments of Hayonim Cave, Israel: diagenetic processes and archaeological implications. Journal of Archaeological Science, 31: 1289-1308. http://dx.doi.org/10.1006/jasc.2001.0790

Yuan D., Cheng H., Edwards R.L., Dykoski C.A., Kelly M.J., Zhang M., Qing J., Lin Y., Wang Y., Wu J., Dorale J.A., An Z. \& Cai Y., 2004 - Timing, duration, and transitions of the Last Interglacial Asian Monsoon. Science, 304: 575-578. http://dx.doi.org/10.1126/science.1091220 